South Dakota State University

Open PRAIRIE: Open Public Research Access Institutional Repository and Information Exchange

Bulletins

South Dakota State University Agricultural

Experiment Station

8-1-1953

\title{
TVA Land Acquisition Experience Applied to Dams in the Missouri Basin
}

K. Kristjanson

Follow this and additional works at: http://openprairie.sdstate.edu/agexperimentsta_bulletins

\section{Recommended Citation}

Kristjanson, K., "TVA Land Acquisition Experience Applied to Dams in the Missouri Basin" (1953). Bulletins. Paper 432.

http://openprairie.sdstate.edu/agexperimentsta_bulletins/432

This Bulletin is brought to you for free and open access by the South Dakota State University Agricultural Experiment Station at Open PRAIRIE: Open Public Research Access Institutional Repository and Information Exchange. It has been accepted for inclusion in Bulletins by an authorized administrator of Open PRAIRIE: Open Public Research Access Institutional Repository and Information Exchange. For more information, please contact michael.biondo@sdstate.edu. 
BULLETIN 432 AUGUST 1953

\section{TVA LAND ACQUISITION EXPERIENCE}

Applied to Dams in the

\section{MISSOURI BASIN}

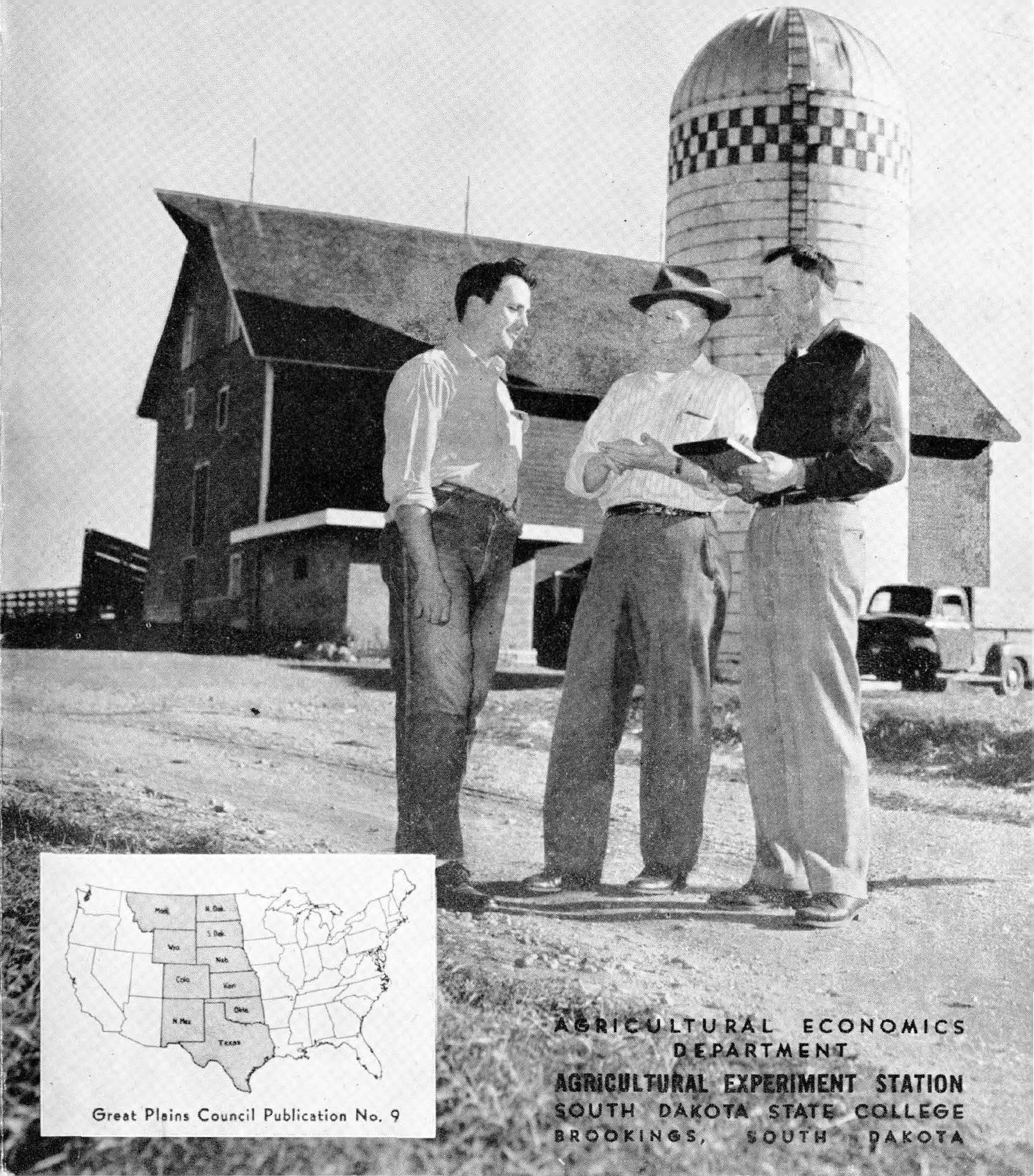




\section{Great Plains Council}

The publication of this report is sponsored by the Great Plains Council. It is one of a series dealing with problems of the Plains.

The Council is composed of the Directors of the Agricultural Extension Services of Colorado, Kansas, Montana, Nebraska, New Mexico, North Dakota, Oklahoma, South Dakota, Texas, and Wyoming; the Directors of the Agricultural Experiment Stations of Colorado, Kansas, Montana, Nebraska, New Mexico, North Dakota, South Dakota, Texas, and Wyoming; and representatives of agencies within the U.S. Department of Agriculture that are directly concerned with the advancement of agriculture in these states.

\section{Tenure Committee}

NORRIS J. ANDERSON

University of Nebraska JOSEPH ACKERMAN

Farm Foundation

B. H. KRISTJANSON

North Dakota Agricultural College

CHARLES MARSHALL

Farm Bureau Federation

HARRY A. STEELE

JOHN MUEHLBEIER

Bureau of Agricultural Economics

ALLEN R. CLARK

South Dakota State College

\author{
AARON G. NELSON \\ Farm Credit Administration \\ WILFRED H. PINE \\ Kansas State College \\ R. T. BURDICK \\ Colorado A. \& M. College \\ LAYTON S. THOMPSON \\ Montana State College \\ E. DEAN VAUGHAN \\ University of Wyoming \\ DON WANNER
}

Farmers Home Administration

OBED A. WYUM

Farmers Union

This study was given general direction by the following sub-committee:

\section{NORRIS J. ANDERSON}

University of Nebraska

B. H. KRISTJANSON

North Dakota Agricultural College

JOHN M. DEWEY

Missouri Division of Resources and Development

\section{KRIS KRISTJANSON}

South Dakota State College and Bureau of Agricultural Economics

WILFRED H. PINE

Kansas State College

JOHN MUEHLBEIER

Bureau of Agricultural Economics

The field work for the study was conducted and the report prepared by Kris Kristjanson, cooperatively employed by the Bureau of Agricultural Economics and the South Dakota State College Experiment Station.

A portion of the funds made available by the Farm Foundation to the Tenure Committee was allocated by the Committee to pay for field work.

Stephen C. Smith of the Agricultural Relations Division, TVA, gave valuable assistance throughout the study. Other members of the organization were also very cooperative in making records and information available to the author.

The Tenure Committee acknowledges the assistance of the following members of the Agricultural Experiment Station, University of Tennessee: Professors Irven Long, Howard Bonser, Ben Luebke, and Robert Spitze. Several members of the Agricultural Extension Service also facilitated the collection of information.

This report was published by the South Dakota Agricultural Experiment Station. Single copies may be obtained from any of the cooperating State Agricultural Experiment Stations. 


\section{Table of Contents}

Introduction _.._- 5

Purpose of Study _.__ 5

Sources of Information ..______-_- 6

Issues Involved in the Study

TVA Procedures in Acquiring and Managing Reservoir Land _..-_-_-_-_-- 9

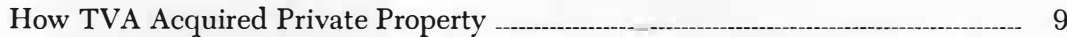

TVA Price Policy _.__ _ 9

TVA Condemnation Procedure _.______________- 10

Effect of Organization _.____- 11

Appraisal Procedures _. 12

Land Buying

Time Allowed Owner _.._____-___- 14

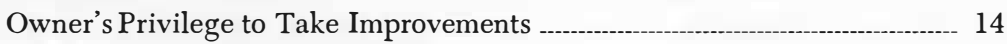

Family Relocation in TVA Area _.___-__- 14

How TVA Met Special Problems

Adjustments with Local Units of Govenment

Handling a Special Case of Consequential Damages _._________-__- 18

Adjustments with Towns _..____ 18

Landowners' Views of TVA Land Acquisition Procedures _.__ 19

Landowners' Suggestions for Improving Procedures _.__ 20

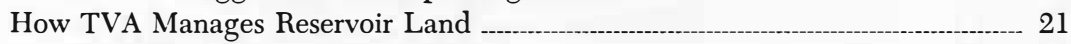

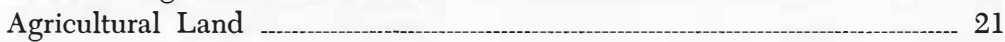

Recreational Lands _._- 22

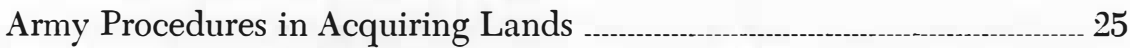

Acquiring Private Property _.__ 25

Acquiring Indian Land ... 28

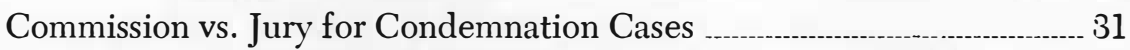

Rules of Civil Procedure in Condemnation Cases _.___________-__-_- 31

Summary of Supreme Court and Justice Department Views _._-__-_-__-__-_-_. 35

Comparison of Commission System and Jury Trial _.__ _ _ _ _ _ 35

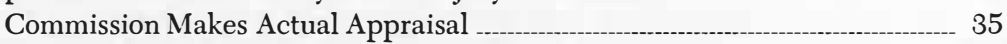

Commission Results in More Uniformity ..._. 36

Commission is Less Time-Consuming and More Convenient _.___- 37

Jury Trials Take More Time _._-____-_ 37

Summary of Commission Experience by TVA _._______- 38

Comparison of Land Acquisition Experience in Army Engineer and

TVA Reservoirs _.._-_____- 39

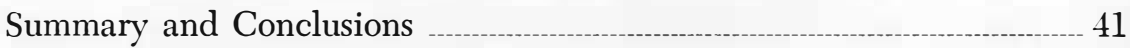

Applications to Missouri Basin _._. 44

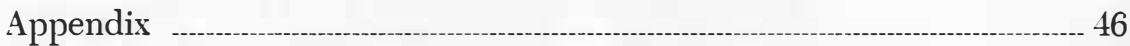

Reservoir Studies 


\title{
TVA Land Acquisition Experience APPLIED TO DAMS IN THE MISSOURI BASIN
}

\author{
By Kris Kristjanson ${ }^{1}$
}

$\mathrm{T}$ HOUSANDS of families have been affected in recent years by the purchase of large acreages of land by Federal agencies for reservoir purposes. The number of families in each reservoir is relatively small. For this reason it is often difficult for them to get adequate consideration of procedures used in taking their land. Also distances between reservoirs are great, which makes it difficult for one group to benefit from the experience of another. ${ }^{2}$

Although part of the land needed for reservoirs in the Missouri Basin has been acquired, much additional land remains to be bought. More than $2 \frac{1}{2}$ million acres are within proposed reservoir sites. Of this land, about $1 \frac{112}{2}$ million acres will be above the elevation frequently flooded and can be leased for agricultural use even though it is subject to occasional flooding. More than 5,000 farm families will be displaced; many have already moved.

Several considerations involved in land acquisition for reservoirs are also present in other programs. One of these factors is the application of the right of eminent domain, but there are also others as brought out in this report. Various procedures for land acquisition and management must be periodically examined to assure equitable treatment of people affected. Those affected adversely by river basin programs are often not adequately compensated and are usually not the ones who get the benefits.

Each governmental agency should benefit from the experience of every other agency in dealing with problems of this kind. Toward this need, the land acquisition and management experience of the Tennessee Valley Authority was studied. This agency has acquired approximately 20,000 tracts of land and has tried new methods. It is im-

portant, therefore, to evaluate what success it has attained. From such evaluation some insight may be gained. which bears directly on the problems of the Missouri or other river basin programs.

\section{Purpose of Study}

It is the purpose of this study to (1) analyze the concepts and procedures used in acquiring private land under the right of eminent domain, (2) analyze and compare TVA land acquisition, land management, and relocation procedures with those used by Federal agencies in the Missouri Basin, and (3) determine the extent to which meth-

\footnotetext{
${ }^{1}$ Agricultural Economist, South Dakota Agricultural Experiment Station and the Bureau of Agricultural Economics.

${ }^{2}$ Several studies have been made of local effects of large dams. The most recent, "Reducing Adverse Effects of Reservoirs," sponsored by the Tenure Committee of the Great Plains Council, pointed to a need for broadening these investigations. See "Reducing Adverse Effects of Reservoirs," Great Plains Council Pub. No. 6, Agricultural Experiment Station, Kansas State College,
} 
ods used by TVA may aid in resolving problems found in the Missouri Basin.

\section{Sources of Information}

Analysis of the TVA experience is based on previously published reports and on interviews with farmers displaced by reservoirs, businessmen, lawyers, commissioners and judges who had experience with condemnation cases in the TVA area and elsewhere, and members of the TVA staff. Of the people interviewed, 69 were farmers and 26 were businessmen or other local leaders. In addition, the problem was discussed informally with many other people during the course of the study.

The farm people interviewed were displaced by the Kentucky, Cherokee, and Fort Loudoun reservoirs. These areas were selected following discussion with personnel from the University of Tennessee, TVA staff members, and other inter- ested people. The Kentucky Reservoir is in an area somewhat similar to the Wappapello Reservoir, Missouri, which had been studied earlier (Fig. 1). Land acquisition was carried on for the Kentucky Reservoir between 1938 and 1943, about the same time as for Wappapello. Farm conditions and the general level of prosperity were comparable. Thus it was possible to compare the effectiveness of different procedures used by TVA and the Army Engineers.

Analysis of legal aspects of land acquisition is based on published reports of the U. S. Supreme Court and the Justice Department as well as on interviews.

Information on procedures used by the Army Engineers was obtained from several previous studies as indicated above. In addition, some study was made of procedures used by the Army Engineers in acquiring Indian lands.

Fig. 1. Location of reservoirs in the Tennessee Valley

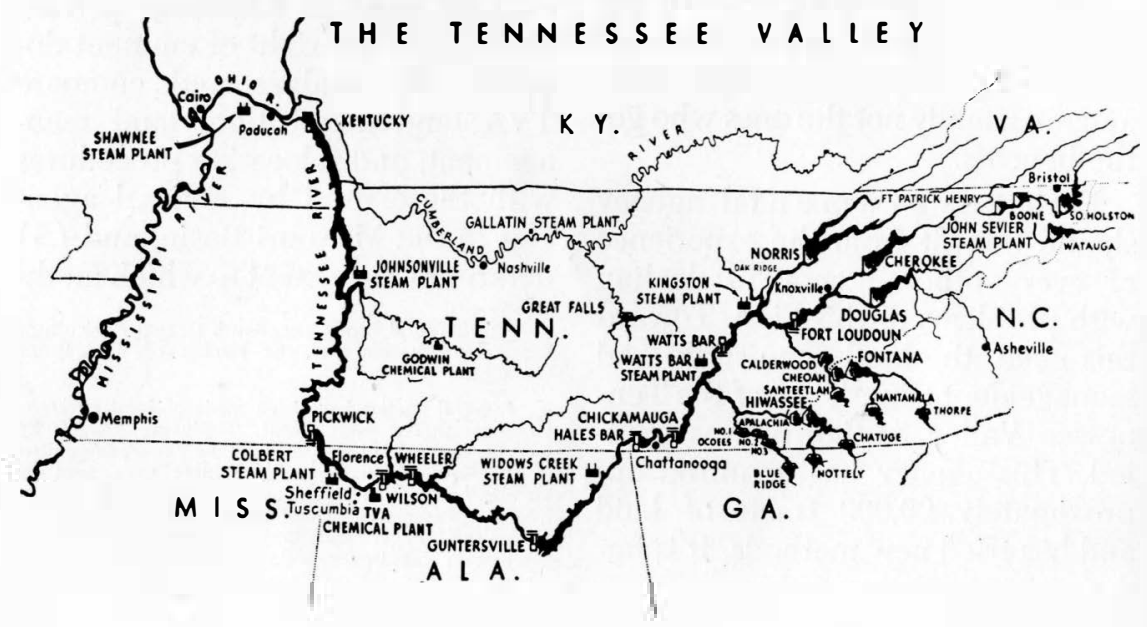




\section{Issues Involved in the Study}

Federal agencies may acquire land for reservoirs either by purchase or through condemnation. This is an important distinction, insofar as TVA is concerned, because of the difference in price policy followed under the two methods. All of the agencies, however, are guided somewhat by their anticipation of what the courts might do if condemnation is necessary.

When private property is taken for a public purpose, the Constitution requires that the owner be paid "just compensation" as determined by due process of law. The question of what constitutes just compensation is a difficult problem. The courts have defined it as a "fair market value." This term is further interpreted to mean "the price a willing buyer would pay a willing seller." The courts have also said that the landowner should be in the "same pecuniary position" before and after the taking. Although these two statements were meant to be different ways of expressing the same idea, the courts have placed the emphasis on the willing buyerwilling seller concept. The Department of Justice, which handles the condemnation cases for the Federal agencies, with the exception of TVA, has also placed emphasis on the willing buyer-willing seller concept.

Federal agencies, including TVA, follow this somewhat rigid interpretation of the concept of just compensation when land cannot be purchased and must be condemned. On the other hand, when land can be bought without condemnation, TVA does not consider itself bound by a narrow interpretation of this concept. TVA is of the opinion that in buying land it may adopt appraisal procedures that take into consideration actual costs or losses sustained by landowners in the process of getting re-established, which need not necessarily be included in a strictly legal sense. Other Federal agencies follow the restricted concept of just compensation even when buying land. ${ }^{3}$ TVA does not hold that its appraisals may be arbitrary nor based entirely on considerations of administrative expediency. Nevertheless, in buying land TVA considers that it has much broader discretion in determining the price to be paid than is the case after the matter is submitted to judicial determination. This report attempts an analysis of the results that follow the use of different concepts adopted by some of the Federal agencies.

There are no absolute standards which can be used. The problem is one of assembling as much relevant information as possible as a basis for a judgment of value. Reasonable men may have wide differences of opinion as to a fair value for a given piece of property.

In assembling evidence or information the administrator is guided by some definition of just compensation. This definition provides a guide for the selection of evidence

${ }^{3}$ The method used to determine just compensation in condemnation proceedings is not the only method of arriving at the value of property being acquired by the Government. The Fifth Amendment does not prohibit agreement as to what is just compensation. See Albrecht vs. United States 329 U. S. 599, 602. 
and influences the final judgment of what is just compensation.

For this reason, it is important to understand the differences in definition used by various Federal agencies. For example, the TVA maintains that if people are to receive just compensation they should be able to re-establish elsewhere and be at least as well off after the property is taken as they were before. The Corps of Army Engineers, on the other hand, is guided by the traditional legal definition of just compensation; namely, that price which a willing buyer would pay a willing seller.

When private land is taken for a public purpose there are generally three interest groups involved: the administrative agency, the taxpaying public, and the landowner. ${ }^{4}$ The landowner has an interest in what price he will receive for the land taken. The public has an interest in paying no more and no less than fair and reasonable prices. The Government agency charged with the responsibility of carrying out the program has an interest in paying a price which is satisfactory to both the landowner and the taxpaying public. The Government agency has an interest in carrying out its land acquisition program in such a way that it does not create unnecessary dissatisfaction among the people affected. If a Government agency is to carry out its work effectively, it must have a reasonable degree of satisfaction among the people affected.

There is a wide variation in the extent to which the interests of these groups are reflected in different situations. This difference re- sults in different price policies. The extent of influence of the various interests in the valuation process affects the determination of just compensation for land taken under the right of eminent domain.

In order to get some insight into the valuation process, analysis is made of three situations where the Federal Government is acquiring land for reservoirs. These are: (1) TVA acquiring private land, (2) the Army Engineers acquiring land for reservoirs from individual landowners, and (3) the Army Engineers acquiring Indian lands from a tribal council. Each of these cases differs from the other in the valuation process. Each situation is analyzed with a view to getting guides for improving procedures for acquiring land under the right of eminent domain.

Administrative procedures used by Federal agencies in making adjustments with local units of government for loss of property are another issue. Here again the agencies have interpreted their responsibility in different ways. The problem is how to arrive at a valuation that is reasonable to all parties concerned; namely, the local unit of government, the taxpayer, and the administrative agency. This also applies to cases of consequential damages.

${ }^{4}$ This process is a transaction in which the landowner and Government try to reach an agreement as to the price of land. In this transaction the public agency assumes the responsibility of protecting the general public interest. This general public interest includes the interests of the agency, the landowner, and the taxpaying public. If the landowner believes his interests are inadequately represented in the appraisal of his property he has recourse to the courts. The courts assume the general public interest will be best served by allowing specific interest groups to present evidence in support of their claim. Out of the conflicting testimony the courts usually arrive at a compromise valuation which is believed to be in the public interest. 


\section{TVA Procedures in Acquiring and Managing Reservoir Land}

\section{How TVA Acquired Private Property}

\section{TVA Price Policy}

Administratively, TVA took the position that the landowner should be at least as well off after the taking as he was before. It tried to attain this objective through its appraisal procedures and the relocation program carried on in cooperation with the Agricultural Extension Services.

The price policy of TVA is best illustrated by the following quotation from its appraisal manual: "The Authority offers to purchase the lands and rights it needs at prices which will enable the owners, if they have to move, to relocate and re-establish themselves in situations which will afford them advantages at least equal to those they now enjoy; or if they do not have to move to make such readjustments and replacements as are necessary to the continued use and enjoyment of their properties without impairment of their economic positions. It is the policy of the Authority to cooperate with and assist the landowners and not to take advantage of distressed financial conditions or seek to buy lands or rights at minimum prices."

The same idea is expressed in a slightly different manner in the following quotation from a statement by one of its staff members: "The farmer who lives in a reservoir area does not usually want to sell. The loss of his land imposes a bur- den upon him even if he receives a fair price. He must find a new place to live, move his household furniture, move or dispose of his farming equipment and stock, and frequently make other substantial adjustments. If he wants to relocate in the same general area, he must buy his new farm in a seller's market in which he is competing with other prospective buyers whose farms have been acquired for the same reservoir project. These factors are taken into consideration by TVA and an attempt is made to leave the landowner in as good a financial position as he occupied before his land was purchased. This policy is required by considerations of fairness to the landowner and we are satisfied that it pays off in dollars and cents."

In other words, when purchasing land TVA placed the emphasis on equitable treatment of the individual by recognizing the costs and hardships that fall upon the displaced. This had a bearing on the price offered an owner for his property even though the various factors considered were not set out separately. The policy was to pay him enough so that with the other help given, he could come out intact. The objective was just compensation in a broad economic sense.

${ }^{5}$ Charles J. McCarthy, "Land Acquisition Policies and Proceedings in TVA-A study of the Role of Land Acquisition in a Regional Agency," Ohio State Law Journal, Vol. X, No. 1, Winter 1949, p. 56. 
In the early stages of the TVA program, the restricted legal interpretation of just compensation was used. Because of difficulties encountered, TVA re-examined its acquisition policies and decided it should try to pay the landowner the price required to leave him in the same financial position before and after the taking. Finding no legal barriers, it established this policy. It is clear that TVA was motivated by a desire to be fair with the people and to get along with them.

On the other hand, when an owner refused what TVA considered to be a fair price and the land had to be condemned, TVA, in presenting its case in court, followed the old concept of willing buyer and willing seller. That is, in court TVA followed the same concept as other Federal agencies condemning land for reservoir purposes.

\section{TVA Condemnation Procedure}

When TVA is unable to buy private property at its appraised value, the land is condemned. The TVA Act provides that condemnation cases shall be heard by a three-man commission selected by the U. S. District Judge. Usually the judge appoints a lawyer familiar with property values to act as chairman of this commission. A lawyer is appointed because the chairman must be familiar with rules of evidence in order to pass on questions of admissibility and competency at the hearing. The three-man commission inspects the property and hears evidence presented by both TVA and the landowner. Operation of the commission is discussed more fully in a later section of this report.

When TVA presents evidence in condemnation cases to establish the value of property taken, it bases its case on the willing buyer-willing seller concept. The appraisal offered in evidence represents only the amount for which the courts in the past have customarily considered the Government legally liable and may often be less than the initial offer. 'This represents a shift from the idea of placing the landowner in the same financial position to the concept of willing buyer-willing seller.

For example, the TVA may offer $\$ 10,000$ for a farm. If the land-owner rejects this offer, the case is heard by a commission. TVA may then present evidence to show that the land is worth only $\$ 8,000$, or the figure that selected witnesses will testify to be its fair market value. In addition, the landowner is not allowed to remove his buildings, for which a reasonable salvage value is deducted, if property is acquired by condemnation.

Among the reasons advanced for this shift to a willing buyer-willing seller concept under condemnation are (1) a belief that the courts generally favor the landowner as against the Government, (2) a desire to discourage litigation, and (3) a feeling that it is under no obligation in litigation to offer anything other than just compensation as defined by the courts.

Justification for this change in the interpretation of fair market value is not entirely convincing. Although it may be argued that when TVA makes the first appraisal it assumes its responsibility to be one of recon- 
ciling the interests of the landowner, the TVA, and the taxpaying public; when condemnation procedures are used, it would appear it assumes that the interests of both the landowner and the public will be protected by the courts. ${ }^{6}$ When TVA is faced with a court case, it relies on the willing buyer-willing seller concept. Also, it is influenced by the usual court interpretations.

\section{Effect of Organization}

Land Acquisition Staff. The TVA appraisal unit consists of a central staff and a field staff. ${ }^{7}$ The central staff consists of a director, a board of appraisal and review, and a supervisor of titles. The director is responsible for over-all planning, directing and supervising the program, formulating policies, preparing budgets, and exercising the other responsibilities incidental to work of this character. The board of appraisal and review assumes functional responsibility for the appraisal work, appraisal policies, price levels, recruiting and training of appraisal personnel, standard of work done by appraisal personnel and estimates of land costs. The supervisor of titles has functional responsibility for title policies and procedures, training and recruitment of title personnel, and the standard of the work done by title personnel.

On each project there is a completely integrated field staff supervised by an area manager. Assisting him is a TVA appraisal committee, which supervises the field appraisers and timber cruisers; a chief buyer, who is responsible for the buying activities and who has supervision over the buying personnel; and a chief title examiner, who is responsible for the title work and who has supervision of the title personnel. Each field staff has its clerical unit, which maintains the records for the project, prepares the progress reports, and furnishes the necessary clerical and stenographic services.

Relations with Other Divisions. Although this study is not concerned with an appraisal of the over-all effectiveness of the TVA type of administrative arrangement, the effect on specific problems of land acquisition and management is recognized. Several divisions within TVA were responsible for some phase of land acquisition, resettlement and readjustment within the scope of the general policies developed for the entire organization. The Divisions of Law, Agricultural Relations, Reservoir Properties, Regional Studies, Personnel, Office of Chief Engineer, and Division of Finance, participated in this process, together with the Lands Division.

The land acquisition staff works closely with the engineers in determining which lands or rights are needed. These activities are coordinated with the lawyers who handle the condemnation cases. All title clearance work is done within TVA,

\footnotetext{
${ }^{8}$ It is recognized that the interests of these three groups are not unrelated or mutually exclusive. For example, the landowner is also a taxpayer and the Government agency is set up to serve his interests along with those of many others. Similarly, the TVA is organized to serve the broad public interest, which includes both the landowners and taxpayers. However, in analyzing the transaction involving the taking of private land for a public purpose, it is meaningful to distinguish these three general interest groups.

${ }^{7}$ The organization indicated was in effect when TVA was carrying on its heaviest acquisition program. Some changes have been made.
} 
and payments can be made more rapidly than would be possible if more than one Federal agency were involved.

The other divisions also work with the land acquisition people, and the effect of their work on land acquisition and readjustment is reflected in many ways. For example, the Division of Agricultural Relations reflects the interests of farmers and the agricultural community. The Division of Reservoir Property is responsible for relocation and reservoir management, and the contact between land appraisers and those working on problems of relocation affects prices paid for land acquired. The attitude of appraisers toward the people whose land is being acquired is affected by the educational program conducted by the Personnel Division. The Government Research Branch affects the settlement made with local units of government. Through its research activities, this division also affects the over-all administration of the TVA, and the effect on the administration is reflected in turn, in improvement in specific policies and procedures for land acquisition and management.

\section{Appraisal Procedures}

TVA has developed a fairly thorough procedure for the appraisal of lands taken for reservoir purposes. The board of appraisal and review assembles as much data as it can in regard to the specific area to be acquired. The next step is to make a background study of the entire reservoir area. All the appraisal per- sonnel participate in the preparation of this study, which covers all factors that have a bearing on market value. Land sales that have taken place in and near the reservoir during the preceding 10 or more years are studied, analyzed, and adjusted by means of the farm real estate index published by the Department of Agriculture. The study also covers farming practices, soils and soil fertility, crop yields and prices, and other factors that have a bearing on the value of land. It also includes inquiries of qualified residents of the area as to the prevailing views on land values.

After the background study has been completed, various field appraisers make independent appraisals of the same tracts to gain experience before beginning the final appraisal work. The results are discussed with the appraisers by an appraisal committee, which reviews all appraisals for the project, and also by the supervisor of appraisals. This procedure results in a more consistent basis for fixing values. Each member of the appraisal staff gets an opportunity to test his judgment with the judgment of other members of the group.

When the preliminary work is completed, the appraisal of individual tracts is begun. The first step is to notify the landowner by letter that the field appraiser will visit the farm on a specified day. This notification has been preceded by a letter to all landowners explaining the purpose of the project and the necessity for acquiring the particular tract of land. Procedures used in 
arriving at a fair valuation are also explained in the letter.

The appraiser is instructed to see the landowner before he begins his appraisal. He invites the owner to accompany him to show him the various factors that contribute to the value of the farm. When the appraiser has inspected the entire farm, he asks the owner to sign a form acknowledging that his property has been completely inspected.

The appraiser is not allowed to discuss the appraisal with the owner. He makes notes on the various items contributing to the value of the farm and then prepares an appraisal report.

"This report completely describes the property, classifying all the elements of value and giving a very complete and detailed analysis of them, and showing the values assigned to the various items. He also makes a sketch of the tract, indicating by symbols how he divided it for purposes of classification. This report facilitates review by other members of the appraisal staff.

"If there was timber of merchantable value on the property, the field appraiser requested a cruise by the timber appraisal unit and included the results of the cruise in his report. The field appraiser's report was then reviewed by a member of the appraisal committee, and after a committee conference his evaluation was either approved or adjusted. Adjustments and reasons for them were always discussed with field appraisers." 8

8John I. Snyder, TVA's Land Buying Program, February 1946, p. 21 .

\section{Land Buying}

When the appraisals are completed and abstract and titles prepared, a land buyer tries to buy the farm. He discusses the method of valuation with the owner and attempts to get him to accept this price. He does not discuss the details of the appraisal. ${ }^{9}$ The land buyer is not allowed to change the price established by the appraisers. This is called the non-price-trading policy and is similar to that adopted in recent years by the Army.

"This non-price-trading policy was decided upon because it was considered fairer to the majority of landowners, that it would speed up negotiations, and create better public relations. It is fairer to the majority of landowners because a few are in much stronger bargaining positions than the majority. The amount of money involved in the acquisition of a small tract of land makes it uneconomical for the owner to enter into litigation over the value of his property. This is reversed in the case of the larger owner, and he might receive proportionately more if bargaining methods are used."10

As in Army procedure the buyer is not allowed to discuss the details of the appraisal with the owner. Reasons for this policy include the contention that it would lead to endless debate about values placed on individual items, when the only figure of consequence is the total amount offered, and that revealing

${ }^{9}$ Neither TVA nor Army Engineers' procedures permit the land buyer to discuss details of appraisal.

10John I. Snyder, TVA's Land Buying Program, February 1946, p. 7. 
this information would place the Government at a disadvantage in the event of litigation.

\section{Time Allowed Owner}

TVA tried to buy the land it required for reservoir purposes about two years before it was actually needed. Payment was generally made within a month of the time the landowner signed the contract to sell. He was then allowed to use this land without rent until it was actually required by the TVA. An attempt was made to set the evacuation date in the late fall in order that the landowner would have an opportunity to harvest his crop before moving.
This period between time of payment and time the land was actually needed gave the landowner an opportunity to look around for another farm without the loss of a crop season. It also afforded an opportunity to make a gradual transition from one farm to another.

\section{Owner's Privilege to Take Improvements}

The policy of TVA was to allow owners to take improvements. A small salvage value was deducted from the total value to compensate for the privilege. Generally the improvements were of little value to TVA but of some salvage value to the owners. ${ }^{11}$

\section{Family Relocation in TVA Area}

The Agricultural Extension Services of the state colleges and universities in the Tennessee Valley assumed the responsibility for aiding displaced reservoir families. The TVA provided financial aid to employ an assistant county agent and to meet certain other expenses in each of the counties affected by the reservoir. In some instances a home demonstration agent was also employed. These workers were appointed by the colleges with the approval of the TVA. They worked with the county agent's office and were directly responsible to the Extension Service for their work.

In arranging with the Extension Service to provide assistance to farmers and others forced to relocate, TVA recognized that this agency was well qualified and had the confidence of the farmers with whom it had been working for many years. Experience with the relocation program demonstrated the soundness of this arrangement.

These members of the Extension Service made it clear to the people who were being displaced by the reservoir that the relocation program was separate from the land acquisition and appraisal program. They had no power to render financial assistance or adjust the appraisal policy. The function of the relocation service was to help displaced farmers find new homes and farms and make other necessary adjustments.

A complete listing was made of all farms that were available for sale.

\footnotetext{
11John I. Snyder, TVA's Land Buying Program,
} February 1946, p. 8. 
The asking price was recorded. In most areas a qualified appraiser under the direction of the Extension Service appraised each tract to check the reasonableness of the asking price. This information was made available to all the Extension personnel working with the relocation program.

A survey was also made to determine the needs of each family displaced. Information was obtained on the financial status of the family, its size, the condition of the home, the size and type of farm, relocation desires, and other information that would be helpful in relocating the family to its best advantage.

These studies indicated the nature of the problem of relocation. In the early stages of the program, families were predominantly agricultural with little or no industrial experience. In addition, opportunities in nonagricultural activities were limited. Therefore, most of the families who were forced to move wanted to continue to farm.

Although some families were not aware of the relocation assistance offered, many reported that it was very helpful. The county agent kept a list of available farms and arranged tours and individual visits to see these farms. Prospective buyers selected from this list the farms they thought worthy of further investiga- tion. In some instances the county agent took the family out to see a farm which he believed would suit its needs. No attempt was made to persuade the displaced family to buy a particular place. The actual choice of farm was left to the individual. Negotiation over price was also left to the prospective buyer and seller.

An important function of the relocation service was to widen the area of choice of a farm through a better knowledge of what was available in the land market. This program helped many families make better adjustments than would otherwise have been possible. County agents report that many of these families continued to seek help from the regular Agricultural Extension Service when they settled in their new locations.

In addition to helping displaced families make a better adjustment, the relocation program also helped check land inflation. When the asking price was found to be unreasonable, the farm was listed in a separate category. Prospective buyers were told about these farms only when they were unable to find a suitable farm in the preferred list. This procedure had the effect of making prospective sellers keep their asking price within reasonable limits. 


\section{How TVA Met Special Problems}

\section{Adjustments with Local Units of Government}

The objective of the TVA was to leave an area as well off after the program was initiated as it was before, or to minimize the injury to the community. This basic idea was the same as the interpretation of just compensation for private lands. To help carry out this objective it made payments in lieu of taxes to state and local governments. It also replaced or made cash settlement for roads except where the need for such roads was eliminated by depopulation. Schools and other property destroyed by the reservoir were paid for in cash.

Payment in Lieu of Taxes. The TVA payments in lieu of taxes are basically a percentage of the gross proceeds from power sales. The percentage amount is apportioned among the states by a formula which gives equal weight to power revenues from each state and to value of TVA power property located in each state. If the amount thus apportioned to any state for any year is less than former state and local property taxes on acquired power property (including reservoir land allocated to power), the difference is made up by a supplementary payment which becomes an additional charge against TVA power operations. Provision is made so that payments, equal to former county and district property taxes on power properties and reservoir lands purchased by TVA and allocated to power, are made directly to counties affected. The amounts paid the counties are deducted from the amounts otherwise due the respective states. The percentage rate of payment is based on the gross power proceeds of the preceding year, graduated downward from 10 percent paid in 1941 to 5 percent payable in 1949 and each year thereafter. ${ }^{12}$

TVA payments, unlike those of some other Federal agencies, are made to states and counties without congressional instructions or suggestions on use of the funds. Inasmuch as the payments are neither tax revenue nor grants-in-aid, they are not subject as a rule to the legislative and administrative provisions that control the handling of such funds. This means that state and county officials have considerable freedom in the use of these funds. So far as is known this has not resulted in a misuse of funds.

The State of Georgia treats its share as utility property taxes, and transfers the equivalent of former municipal taxes to the municipalities concerned. Mississippi receives the payment into the State general fund, and under legislation of 1942, the State Auditor apportions to the municipalities an amount equal to the former municipal taxes included in the minimum payment. ${ }^{13}$ In 1943, the State Treasurer of Tennessee was directed by the Legislature to pay to the municipalities one-half of the former municipal property

\footnotetext{
${ }^{12}$ Tennessee Valley Authority, Report on Section 13 of the TVA Act, December 1944, p. 11.

${ }^{13}$ General Laws of Mississippi, 1942, Chap. 223 (H.B. No. 466).
} 
taxes included in the minimum payment subject to certain qualifying conditions; the remainder of the payment to remain in state general and school funds. ${ }^{11}$ This statute was later repealed by implication by enactment of another law ${ }^{15}$ similar in its provisions to the North Carolina statute.

In Tennessee the later Act has been interpreted by State officials to provide only for reimbursing the reservoir counties of the State for the former county taxes on TVA reservoir lands not allocated to powerand thus not directly replaced by TVA itself. North Carolina divides the TVA payment to the state among the state and the counties and municipalities in which the TVA property is located. The distribution among these jurisdictions is in the same proportion as tax levies would be distributed if the TVA property and operations were in private ownership. ${ }^{16}$ Kentucky, beginning July 1,1954 , will divide its TVA payment among all state and local units of government in which TVA power property is located in approximately the same ratio as actual taxes would be levied if the properties were not exempt from taxation. ${ }^{17}$ Alabama and Virginia retain the entire state payment for the use of the state government, treating it as miscellaneous receipts into the general funds.

Roads. TVA worked with county officials in making plans for the relocation of highways within their jurisdiction. After the plan was drawn up, TVA estimated costs and the terms of settlement were negotiated with the County Board. Some roads were not replaced because there was no longer a need for them. The policy which governed was to provide reasonable access to property.

The alternatives presented the County Board were cash settlement or actual replacement. Most counties requested actual replacement of the facilities. It was generally agreed that the roads constructed by the TVA were better than the roads that existed before the program began.

Schools and Educational Facilities. When schools were disrupted by the reservoir program, TVA, with the assistance of the local school districts and state departments of education, tried to make adjustments that would lead to an improvement in the existing educational facilities in the community. Payments made for loss of schools were based on the physical value of the property. ${ }^{18} \mathrm{But}$, in some communities the acquisition made possible the consolidation of several small school districts, and the money paid the local district was used in the new consolidated school district. TVA personnel provided professional advisory service in planning for improved school facilities.

\footnotetext{
${ }^{14}$ Public Acts of Tennessee, 1943, Chap. 111 (S.B. No. 399).

${ }^{15}$ Public Acts of Tennessee, 1947, Chap. 31.

${ }^{18}$ Public Laws of North Carolina, 1941, Chap. 85. ${ }^{17}$ Kentucky Acts, 1952, Chap. 61.

${ }^{18}$ TVAt considered replacing school buildings in place of offermng cash settlement but decided against it. The reason advanced for not favoring this policy was that the limit of liability would be difficult to establish. The limit of liability was determined in the case of road relocation, so it could also be determined where school facilities were invo!ved. When schools must be acquired, the value of the physical property may not be adequate to provide equally serviceable facilities elsewhere. For example, a school luilding may be old but provide adequate classroom space. However, the appraised valuc may not be adequate to build a new school with comparable accommodations. In these cases, it seems that the public should either construct or pay the cost of an equally serviceable building.
} 


\section{Handling a Special Case of Consequential Damages}

In relocating the railroad between Camden and Denver, Tennessee, the original depot site serving the community of Denver was bypassed. This left without rail facilities a grain company which, according to lease agreement, had placed buildings, machinery, and equipment on the land of the railroad company. A portion of this land was to be inundated. Replacement would have cost $\$ 26,000$. It was decided by mutual agreement not to move this property nor build a spur but to settle with the grain company for $\$ 15,000$. The grain company entered into a release of damage agreement. The railway released TVA from all claim on account of loss of rental to the railway and from obligation to construct a spur line from the railroad to the site of the grain company.

In contrast, the Army Engineers, faced with a similar problem in the Missouri Basin, considered it had no responsibility nor authority to work out such adjustments. An elevator company, in the same position as the one mentioned above, moved its plant at a cost of $\$ 11,000$ and received no compensation, although it is understood that a bill has since been introduced in Congress to provide relief. Even if paid, the delav and uncertainty has been a hardship on the owner. ${ }^{19}$

${ }^{10}$ Report No. 1 to the Nebraska Coordinating Committee for Missouri Basin Resource Development, entitled "Some Local Problems in Connection with Harlan County Reservoir," February 1951 revised. Mimeo. Available at Univer sity of Nebraska.

\section{Adjustments with Towns}

Adjustments with towns affected by a reservoir pose many difficult problems. Each situation is unique and requires special consideration. TVA had considerable administrative discretion in dealing with these problems.

Dwelling houses or facilities on the fringes of quite a number of towns have been acquired, but so far as is known, only two school buildings were seriously affected, at Dayton, Tennessee, and at Decatur, Alabama. In both instances, the school grounds were raised above high-water levels. Sump-pumps were installed in the school basements, and main streets affecting access were raised. At Kingston, Tennesee, the high school football field was raised because of danger of soakage from the reservoir. Water works, sewers, and sewage-treatment plants were affected in a number of cities. The general formula for adjustment was for TVA to replace such facilities in at least equal condition to that existing before the reservoir was created.

In each case TVA was asked to make the adjustments rather than to pay cash to the cities and have it make its own adjustments. The actual amounts paid or the manner of replacement were matters of negotiation between the TVA and the local unit of government. Terms of the settlement varied with each situation, and the administrator, acting in behalf of the Board of Directors, had authority to make adjustments which he deemed reasonable. 


\section{Landowners' Views of TVA Land Acquisition Procedures}

From interviews with individuals displaced by TVA reservoirs, it was learned that the people, with few exceptions, were well satisfied with the procedures used in arriving at a value for their land. In general, they believed the prices paid for land taken were adequate to permit them to buy comparable property elsewhere.

Although the general level of prices was considered fair, there was a belief among many landowners that the prices paid for the smaller, less productive farms were relatively higher than the prices paid for the larger, more productive farms. Some owners of large farms thought their land was undervalued in relation to the smaller farms in the neighborhood.

This may be explained partly by the fact that the procedures used by TVA did, in effect, result in an allowance for disturbance costs. That is, TVA tried to pay landowners enough so that they could get established in similar circumstances elsewhere. In so doing the per acre value of small farms was increased more than the per acre value of big farms.

Satisfaction with the prices received for the land cannot be attributed entirely to the appraisal procedures. The effect of the total TVA program influenced the people's attitude toward the land acquisition program. The following quotation from an interview with a landowner displaced by a TVA reservoir is a typical reaction of the majority of people interviewed. "TVA appraisers were fair in their appraisals.
Only two in this community had a law suit. These men got slightly higher awards but would have been better off to settle in the first instance.

"At the time the land was taken, most people could buy equally good or better land for the money received. The relocation program was very good and particularly helpful to those who were not in a position to look for a good place to buy.

"TVA power rates are about onehalf what private companies charge. Now everyone has most electrical conveniences in their homes. If TVA power was not available, people would have to do without refrigerators, electric stoves, ..."

A few people in each reservoir area were apparently dissatisfied with TVA appraisal policies and procedures. These were generally fairly well established farmers in their community. There is some evidence that TVA land acquisition people identified the landowners in each community with whom they thought it would be difficult to deal. The field appraisers would appraise their farms at the most strategic time; frequently this would be toward the last. Most of those interviewed who were antagonistic toward TVA are in this category. Whether all of these owners would have been difficult to deal with had they not felt discriminated against is not known.

In a few instances antagonism was intense for still other reasons and resulted in bitter criticism of the total TVA program. This attitude is ex- 
pressed in the following statement made by a good farmer who was forced to move from one of the TVA reservoirs:

"There is no consideration of individual rights. Posts which I was hauling from the hills were burned. I was pulling fence posts to take with me when TVA came along and cut the posts near the ground. I was moving my hogs to the new place when TVA men came along and said if the hogs are not moved by tomorrow we will cut the fence and run them out. The next day I took my gun along. The only experience in my lifetime which I would not like to repeat is my experience with the TVA.

"People tried to get some consideration of their interests with no avail.

"The relocation program did some good in that we were able to get a list of farms for sale.

"I was able to find a good farm but the money we received was not sufficient to buy property comparable to what we lost. I was left with a strip of hill land; the land- owner should have a choice of selling this."

No attempt was made to ascertain whether there was justification for this complaint.

Landowners were sometimes critical of the TVA for practices that were indirectly related to the land acquisition policy. For example, TVA is reported to have burned good timber rather than sell it or give it away to local people. TVA personnel reported that in some cases it tried to give this excess timber to local people but was unable to get them to move it away. The most feasible alternative then was to burn it because the reservoir area had to be cleared by a certain time. In cases of this kind, information needs to be made available to explain why certain action is necessary.

\section{Landowners' Suggestions for Improving Procedures}

Although prices paid by TVA were generally considered fair and reasonable, landowners had several suggestions for improving the land acquisition procedures. The following are some of these suggestions:

(1) When only a part of the farm is needed for the reservoir, landowners believe they should be given the choice of selling all or part of the farm. ${ }^{20}$ The policy of buying only what is needed for reservoir operations often leaves the owner with a strip of hill land which cannot be operated as an economic unit. Landowners generally believe they should have a choice of selling the entire farm or accepting a severance allowance and retaining the part of the farm not needed by the TVA.
Some of this land becomes valuable for recreational purposes. However, the landowners believe they should have a choice of selling all the farm or retaining a part of the hill land.

${ }^{20} \mathrm{TVA}$ has followed different policies with respect to the amount of land to be acquired. In the early years of the program the policy was to acquire wide areas around the lake. This policy grew out of the particular needs of the time. During the early 1930's, farm incones were generally low and large areas of land were classed as submarginal for agricultural purposes. The prevailing Federal policy was to get this land out of agricultural uses. Forestry and recreational developments were being encouraged.

The TVA land acquisition policy was developed at a time when these ideas prevailed. When the first dam (Norris) was being built, a large protective belt was bought aroind the lake. TVA bought these large areas to gain control of the land for program purposes as well as to protect some of this submarginal land from erosion, and so forth.

Since the beginning of the TVA program, the land buying policy has gradually changed. First it bought large areas of land surrounding the reservoir. The present policy is to buy a minimum of land required for reservoir operations. The results of this policy are reflected in the Douglas Reservoir, for instance, where problems have arisen because people were left with uneconomical units. 
(2) Almost all the landowners interviewed believed the landowner should be allowed to see the breakdown of the appraisal. They wanted to know what had been allowed for cropland, buildings, timber, and so on. ${ }^{21}$

(3) Many landowners thought they should have some representation in the appraisal process. The suggestion was frequently made that appraisals should be by a threeman board with representation of landowners, the TVA, and a third man representing neither the landowner nor the TVA.

\section{How TVA Manages Reservoir Land}

In addition to problems of land valuation, people are also affected by procedures used in land management, leasing of recreational areas, and sale of excess lands.

Through experience and study the TVA has developed some new ideas for dealing with these problems. The ideas and experiences believed to be useful to people in other areas faced with similar problems are discussed below.

\section{Agricultural Land}

In the early stages of development the TVA emphasized a high degree of technical planning. This required the control of the land area around the lakes. As the program advanced, emphasis was shifted to less central planning and more state and local participation. This change in emphasis also contributed to the change in land buying policy. The prevailing policy in TVA is to acquire easements and keep purchases of land at a minimum.

Present land management problems of the TVA center around renting lands for agriculture and recreation and selling excess lands.

Licensing of Agricultural Lands. For many years TVA has contracted with associations of farmers for advisory assistance in licensing reservoir lands available for agriculture. Sometimes these are the County Soil Conservation Associations sponsored by the Extension Service. Where there were no County Soil Conservation Associations, a Land Use Association was organized. These groups advise the TVA on best land use and also make suggestions on licensing policy.

Although bids are invited for the use of the land, the associations in special cases recommend that the land be rented to a man who has not made the highest bid. These decisions are based on the circumstances of the case. The need of the land by the applicant and the plans for use are taken into consideration. The TVA reserves the right to make final judgment but usually the judgment of the local association is accepted. This procedure is novel in that most other Federal agencies do not rely on local associations of farmers to carry out this kind of work.

${ }^{21}$ In the one reservoir in Nebraska where this was tried, the results were satisfactory. See Report No. 2 to the Nebraska Coordinating Committee for Misscuri Basin Resource Development, entitled "Some Local Problems in Connection with Trenton, Enders, and Medicine Creek Reservoirs," November 1951, Mimeo. 
Rates are reviewed annually, but the association generally recommends that the present operator have the opportunity to renew his license. This provides stability of tenure. Although the local association makes the recommendation as to who should get use of the land, the TV 1 reserves the right to make exceptions.

In the last few years, five-year licenses have generally been granted. This means that the property is not opened for bid each year.

Flexible Rental Rates. A new policy of flexible rental rates is being tried by TVA but has not been in effect long enough to judge its success. This policy is to set the license rate at auction the first year; during the four succeeding years the price is adjusted up or down as indicated by changes in the U. S. Department of Agriculture index of prices received as of November 15 for all farm crops in the state in which the land is located.

This policy has met with favor with some administrators in the field offices, but others say the procedure is too complicated and increases the problems of administration. They also say that renters do not understand this type of agreement and much prefer to have a fixed rate for five years. In this they may be influenced by a favorable outlook. At present there is not enough experience on which to judge the effectiveness of this kind of arrangement. Adequacy of a flexible rental rate can only be tested when administrators are sympathetic with the idea and willing to try it out.

\section{Recreational Lands}

In the early stages of the TVA program, there was a high degree of centralized planning in recreational development. Since that time a shift has been made to a greater reliance on the state and local units of government to carry out this work. At present most of the responsibility in recreational development of TVA land is carried on by local groups, and TVA personnel provide technical guidance when called upon to do so.

The present policy of TVA is (1) to reserve ample land for lease and ultimate transfer to public agencies and (2) to sell recreational areas suitable for private development by individuals and businesses after access roads are provided.

Before TVA sells excess lands, it ascertains in consultation with state and local planning and recreation agencies, what lands should be kept in permanent public control, in order that as many people as possible can have access to the lakes for boating, fishing, and other types of recreation. TVA then transfers these lands for a nominal consideration to public park and recreation agencies that will assume responsibility for their development and operation.

Leasing. Much of the land acquired by TVA is suitable for boat docks and other recreational uses. The policy for handling these areas has developed through three stages:

1. Licenses granted for an indefinite period but revokable by either party on 30-days' notice.

2. Long-term leases.

3. Selling recreation sites to pri- 
vate individuals or local groups.

The 30-day revokable licenses, as well as long-term leases, were granted after the areas had been advertised. As the rental was fixed by TVA in advance, the selection of a license was based on an appraisal of the applicant's qualifications to do the job, including his financial ability, business experience, and plans of development and operation. Members of the TVA staff made this selection, and experience showed that there was no assurance that a good operator would be selected.

This policy has been changed to granting a long-term lease. Usually this is a 19-year lease. The rates are based on a certain percentage of gross income. The present rate is 3 percent of the first $\$ 20,000,2$ percent of the next $\$ 10,000$, and 1 percent of anything above $\$ 30,000$. This system was designed to encourage the lessee to expand operations, and it has proved effective for that purpose.

In small operations a license is granted at a flat fee of $\$ 25.00$ per $\$ 1,000$ of gross income. This procedure facilitates negotiations with small operators who do not want, or are unprepared, to keep detailed records.

Selling Excess Lands. TVA follows the policy of selling all surplus lands as soon as it is clear that no program requires its further retention. The various divisions in TVA review reservoir properties to determine which lands are surplus. When a consolidated pattern of development is clear, the land is normally offered for sale at public auction for a specific purpose. The deed may or may not contain restrictive covenants enforcing continued use of the property for the specific purpose. In some cases, as in an area well suited for subdivision for cabin sites, individual deeds may contain restrictive covenants among the purchasers. Deeds to single tracts, however, do not ordinarily do so.

In the case of certain key tracts having unusual possibilities for recreation and little value for other uses, TVA sells land under Section 4KA of the TVA Act. This section authorizes sale or transfer of land "for the purpose of recreation or use as a summer residence, or for the operation on such premises of pleasure resorts for boating, fishing, bathing, or any similar purpose." Under this authority, TVA may sell land either at public auction or through negotiation.

Lands sold under Section 4KA contain a special clause providing that the Government may re-enter and repossess the property in the event it is used in a manner inconsistent with the purposes for which sold.

Whenever it sells land for agricultural or forestry purposes, TVA retains for the public the right of access to a strip 250 feet wide along the waterline for recreation and fishing. This reservation of rights does not permit overnight occupancy or the erection of improvements. In areas where a high degree of recreational development is anticipated, this provision will have far reaching public benefits. Most of the development of outdoor recreational areas 
takes place around some natural or artificial body of water. These areas are now limited and the demand is great for land adjoining waters which can be used for recreation.

Experience in areas like northern Wisconsin shows that the land immediately surrounding lakes is soon acquired by private owners. These people build summer homes and other buildings along the shoreline, and no provision is made for public access. This frequently means that each one of these lakes has only one row of homes or cabins around the lake. On the other hand, if the public were allowed to use the shoreline and public access were provided, summer homes could be built away from the water's edge. This would result in a greater degree of recreational development and make it possible for a larger number of people to enjoy advantages of a given recreational site.

The 250-foot public access easement discussed above is an attempt to retain for the public the right to use the shoreline for recreation and fishing. This policy has been followed on five main stem reservoirs. In some reservoirs such as Norris, the TVA owns the entire shoreline high enough above the normal waterline to assure public access.

The public has made limited use of the privilege provided by this 250 -foot public access easement. In the one case contested in the courts, it was ruled that the Government had the right to prohibit building cabin sites or other structures on a 250-foot strip having this public access easement.

At the present time there is little public understanding of the idea involved. Most people are not aware of the right they have to use this land for recreation and fishing. This may be explained by the fact that the recreation industry has not yet developed to the point where access to the shoreline is limiting further development. The benefits from this provision may not come for 50 years or more. With an increase in number of people using the limited recreational areas, a few public access points will not be adequate to permit a large number of people to benefit from the lake.

When public funds are used to develop a recreation facility of this kind, it is reasonable to make provision for a maximum number of people to enjoy the benefits. 


\section{Army Procedures in Acquiring Lands}

The foregoing analysis has been concerned with the way TVA interpreted its responsibility toward people displaced by its reservoirs, and the administrative procedures used in carrying out this responsibility. It is apparent that by doing a great many things differently, TVA was relatively successful in its land purchase and management work. It is apparent that other Federal agencies could also improve their procedures. This can be seen by a comparison of the procedures used by the Army in acquiring private lands and Indian tribal lands.

\section{Acquiring Private Property}

Procedures used by the Army Engineers when dealing with individual landowners vary slightly between reservoirs but exhibit a fairly consistent pattern.

Price Policy. In a pamphlet issued by the Army Engineers explaining how land is bought for reservoirs, the following statement was made: "In making an appraisal or in determining whether an offer is 'reasonable,' Government representatives are controlled by rules of law as to repayment of 'just compensation' which the United States Constitution requires to be paid for the taking of private property. There are many ways of defining the term, but all mean the same. The 'reasonable market value' has often been defined in court decisions as that which a willing buyer would pay a willing seller, neither being under any threat or force to buy or sell. The rule is applicable even though own- ers within a reservoir project area are often unwilling sellers for reasons that can be understood and appreciated." 22 The above statement is based only on the concept of willing buyer-willing seller and does not recognize that it may also be interpreted to allow owners to retain their same financial position before and after the taking.

The law which authorizes the Secretary of the Army to acquire land in behalf of the United States for flood control projects allows acquisition either through condemnation or purchase. Condemnation proceedings are held in the Federal District Court wherein the land is located. The Secretary may acquire land by purchase from the owner if he "shall fix a price-which in the opinion of the Secretary-is reasonable." The authority to purchase by contract vested in the Secretary of the Army has been delegated by him to the Division Engineer and the District Engineer. In order to determine values, the Division Engineer and the District Office have a staff of land appraisers. These appraisers are employed only upon proof of proper qualifications and experience as professional appraisers. Each appraiser is instructed to apply his professional judgment. Such appraisals are subject to review and modification by a higher authority in the Army.

In a report to the South Dakota

22" Reservoir Land and How the U. S. Buys It," Corps of Engineers, Missouri River Division, Omaha, Nebraska, July 1952, p. 5 . It should be noted that while the title would seem to include all Federal agencies, the report explains only purchases by the Army. 
Coordinating Committee, the Army Engineers made the following statement about its procedures in land acquisition:

"The Army has a qualified appraiser who makes a detailed inspection of each property to be bought. At that time the owner of the property is invited to go with the appraiser in order that all features tending to influence the fair market value of the property may be called to the attention of the appraiser and given proper consideration. In this detailed inspection the various types and fertility of the soils are noted as well as buildings and improvements on the property, and their condition and appearance. Such improvements are considered in their relationship to the operation of the farm or ranch as a whole for its highest and best use. During this inspection the appraiser is at all times, in his own mind, drawing comparisons with properties known to have been recently sold and with those known to be on the market for sale. Upon completion of this inspection the items are then discussed in detail with the reviewing appraiser, and after full consideration has been given to all of these items, an estimate is made as to the total fair market value of the property. A report is prepared for the reviewing appraiser giving the facts and reasoning leading up to the conclusion reached as to value.

"Appraisers are not permitted to negotiate the purchase of land they have appraised. They cannot disclose the amount of their appraisal to the owner at the time the appraisal is made because the estimated value is not final until reviewed and approved by the reviewing appraiser.

"A negotiator next contacts the owner to get an option to purchase the property. The full amount of the estimated fair market value is given the owner together with the estimated salvage value of the improvements, if any."

Determination of What Is Being Appraised. When the appraiser visits the farm to make the first apprais$\mathrm{al}$, he generally tries to see the landowner. If he is not home, the ap- praiser examines the property and writes his report. In Army reservoirs the complaint is often made that the owner was not contacted when the appraisal was made. This makes it difficult for the landowner to know whether the appraiser was aware of the various elements that contribute to the value of the farm. ${ }^{23}$

When the negotiator presents the appraisal figure, the owner invariably asks how the figure was arrived at. The reply is, "Prevailing regulations do not permit the breakdown of the appraisal." Consequently, the landowner often does not know whether the appraiser was aware of all the elements of value.

It is often argued that the owner is not concerned with the breakdown of the appraisal, that he is concerned only with the total value offered for the farm. It is no doubt true that the landowner's chief concern is with the total valuation. However, landowners usually have only an approximate figure in mind which they believe to be the true value of the farm. Usually they recognize that land valuation is a matter of judgment about which reason-

23"'Some Local Problems in Connection with Harlan County Reservoir," Report No. 1 to the Nebraska Coordinating Committee for Missouri Basin Resource Development, February 1951, Revised; "Some Local Problems in Connection with Trenton, Enders, and Medicine Creek Reservoirs," Report No. 2 to the Nebraska Coordinating Committee for Missouri Basin Resource Development, November 1951; "Studies Needed on Local Problems with Large Reservoirs," Report No. 3 to the Nebraska Coordinating Committee for Missouri Basin Resource Development, December 1951, Mimeo., available at University of Nebraska; "Some Local Impacts of Reservoirs in South Dakota," October 29, 1951 Mimeo., available at South Dakota State College; "Local Effects of the Wappapello Reservoir, Wayne County, Missouri, with Suggestions for Lessening Undesirable Effects of Reservoirs," February 1950, available at Division of Resources and Development, Jefferson City, Missouri. The Army originally did not reveal the appraisal figure but tried to buy the land at the lowest possible price; see page 8 , Wappapello Report. Since then the policy of the Army has been improved so that it does not buy land at a figure below the appraised value. 
able men might have wide differences of opinion. But, they do believe that this judgment should be based on a complete knowledge of facts, such as number of acres of cropland, number and kinds of buildings, water supply, road conditions, and other items which contribute to the value of a farm.

In some cases the landowners who had sold land to the Army Engineers reported that they were not told the exact location of the taking line. They were not certain what lands had been acquired by the Army Engineers. In other cases, the appraisers were appraising land without a detailed map showing the exact location of the taking line. Deficiencies of this nature undermine the confidence landowners have in the appraisal procedure. Owners and others who represent the interests of landowners believe that the sole responsibility of appraisal should not be left to the appraisal staff of agencies acquiring land. They believe that the seller should be given access to facts and reasoning leading to conclusions as to value and that it would be mutually beneficial to discuss these elements with the landowner. When information considered vital is withheld, owners question the adequacy of the appraisal.

Representatives of the Army Engineers argue that this would put the Government at a disadvantage. The owner would pick out those items that he believed were undervalued and raise questions about these without saying anything about those items that he believed to be overvalued. They further point out that this procedure would put the
Government at a disadvantage when the land must be acquired through condemnation. For these reasons the Army Engineers believe it is not wise to show the owner the breakdown of the appraisal. ${ }^{24}$

In a Bureau of Reclamation reservoir in Nebraska, the land buyers followed the policy of showing the landowner the breakdown of the appraisal. This procedure proved more satisfactory to both the landowners and the agency personnel. ${ }^{25}$

"Landowners in these reservoir areas also reported wide differences in prices offered for similar property in the same general area. This leads to considerable dissatisfaction when there is no explanation for the differences. In many cases the appraisers might have a very legitimate reason for the difference in appraised value. However, if this is not made known to the people involved, dissatisfaction results." 26

In many cases the Army finds it necessary to transfer appraisers from one reservoir area to another. Sometimes these men are moved from one section of the country to another. Although the type of farming and general cultural pattern may be entirely new to them, these men are often asked to begin making appraisals without adequate time to become familiar with the new area. Even highly competent appraisers

\footnotetext{
${ }^{24}$ Some of the same arguments are advanced by the TVA.

${ }^{25}$ Report No. 2 to the Nebraska Coordinating Committee for Missouri Basin Resource Development, "Some Local Problems in Connection with Trenton, Enders, and Medicine Creek Reservoirs," November 1951, Mimeo., available a t University of Nebraska.

28" Some Local Impacts of Reservoirs in South Dakota," Report presented to South Dakota Coordinating Committee for Missouri Basin Development, October 29, 1951, p. 7, Mimeo., available at South Dakota State College.
} 
require a certain amount of time to become familiar with an area, and there is evidence that often not enough time is allowed. For this reason they are often not able to detect differences in land values that are generally recognized by the local people. This type of error can be reduced by making known to all parties to the transaction the information in the appraisal report.

\section{Acquiring Indian Land}

The Army is required to follow a specific procedure in acquiring land held by the Cheyenne River Sioux Tribe.The Tribal Council, with the support of the Department of the Interior, sponsored a special Act providing for the orderly taking of Indian lands for reservoir purposes. ${ }^{27}$ This Act specifies the procedures to be followed in arriving at a judgment of fair compensation for land taken.

Under authority of this Act the Army Engineers appointed a commercial firm to make an appraisal of the Indian lands to be taken from the Cheyenne Reservation. This firm made the appraisal and submitted a report to the Army Engineers. This report was then submitted to the Tribal Council negotiators for their consideration. After careful review the Council found several errors of fact in the report.

The Chairman of the Tribal Council and other members of the Tribal Negotiating Committee had discussions with the Chief of Army Engineers and with the Secretary of the Interior in Washington. As a result of this conference, it was agreed that a preliminary conference would be held at the Cheyenne Agency and that the final contract conferences would be held in Washington.

The purpose of the first meeting held at the Cheyenne Agency was to lay the groundwork for satisfactory negotiations at the Washington meeting. The groups represented at this meeting were the Army Engineers, the Department of the Interior, and Cheyenne River Sioux Tribe. In the opening remarks the representatives of the Army Engineers said, "The Corps was anxious that all who are concerned with the Oahe Project in any way have a personal knowledge of what the negotiators for the Tribe and the Army and the Interior are trying to do. I want it clearly understood that all the money that is involved in the construction of the Oahe Dam is coming from the people, the taxpayers, and that the Corps has no personal interest in it." 28

The representative of the Department of the Interior made the following remarks with respect to his position, "I feel like a judge, it is my job to see that everybody gets fair play; I represent the taxpayers and it is my duty to see that we don't go beyond what is right and reasonable. It is also my job to see that the Indians are fully compensated for their losses and that they get complete rehabilitation all around."

The attorney representing the Indian Tribe made the following remarks about his position, "I owe no

${ }^{2 \pi}$ Public Law 870, 81st Congress, Ch. 1120, 2d Session, H. R. 5372.

${ }^{28}$ Summary of Oahe Contract Conferences, Chey enne Agency, South Dakota, May 13, 14, and 28, 1952 p. 2. Mimeo., available from Tribal Council, Cheyenne Agency, South Dakota. 
allegiance to the Corps of Engineers or to the Bureau of Indian Affairs; I am quite independent of and for the Cheyenne River Sioux Indians. We are here to try to work out an equitable contract-acceptable to the Congress and acceptable to the Indians. We are not going into condemnation and should not be asked to proceed on decisions of the courts. One question we should ask is, what will we be able to do with the money that will be allocated to us as owners of the land, can the individual restore himself to a position at least as good as that which he enjoys now?"

The above statements indicate that representatives of the Federal agencies expressed a public viewpoint rather than agency viewpoint. The provisions of the Act, however, recognized the existence of private, public, and agency interests and provided for all being taken into account in arriving at a fair valuation of the property taken. The problem was to arrive at a valuation which was satisfactory to all the interest groups.

To arrive at a valuation which is reasonable to both the public and the landowner, the attorney representing the Indians believed the court concept of "willing buyer-willing seller" could not be used. The usual court interpretation of fair market value was not considered adequate to allow the landowner to re-establish himself in a position as good as the one he enjoyed before his land was taken. The representative of the Army said that Public Law 870 involved an approach to the problem that was unique; the paragraph in the law that provided for relocation and rehabilitation of the tribe and its members is entirely different from old Army condemnation proceedings. ( Italics supplied.)

Tribal negotiators pointed to several errors of fact in the appraisal made by the commercial firm. When this point was established, the attorney for the Indians suggested that "the Army and Department of Interior each send a couple of good men to work with the Tribal negotiators to examine the appraisal, tract by tract." ${ }^{29}$ After some discussion, this plan was accepted by the group. It was agreed that the scope of such a committee should be limited to facts. Matters of judgment of value were considered beyond the assignment of the committee. The committee was to arrive at some agreement on the facts, such as number of acres in the taking, location of tracts, land descriptions, improvements, and severance on individual tracts.

A representative of the Army Engineers suggested that a statement be drawn up indicating what had been agreed to during the first day of conference. The following statement was then written and signed by representatives of the Army Engineers, the Department of the Interior, and the Tribal Council.

The significant point in this procedure is that all parties concerned with the appraisal were given an opportunity to review the factual in-

${ }^{29}$ Summary of Oahe Contract Conferences, Cheyenne Agency, South Dakota, May 13, 14, and 28, 1952. Mimeo, available from Tribal Council, Cheyenne Agency, South Dakota. 
formation in the appraisal report. Representatives of the Department of the Interior and the Tribal Council were in a position to insist that all elements of the appraisal report be accurate. Price negotiations have not yet been completed. The procedure provided, however, that, after the above committee reached agreement as to the facts, all the interested parties would be represented when a judgment was made as to the value of the land taken.

In summary then, because the Indians were organized and in a better bargaining position, the procedure used for acquiring Indian lands in the Cheyenne Reservation called for an open discussion by all parties concerned as to what elements of value were to be considered. Secondly, all the interested groups are represented when the final judgment of value is being made. Although the taxpayers are not directly represented by either the Government agency or the landowner, the procedure used should result in a determination of value that is acceptable to the taxpayer.

\section{Summarization of Conferences, May 13, 1952 Cheyenne Agency, South Dakota}

\section{Re: Negotiations with the Cheyenne River Sioux Tribe under Public Law 870, 81st Congress.}

"The parties, directed by Public Law 870,81 st Congress, met in conference in accordance with the agreement dated January 11, 1952, signed by Lewis A. Pick, Lieutenant General, Frank Ducheneaux, Chairman of the Cheyenne River Sioux Tribal Council, and Dale E. Doty, Assistant Secretary of the Interior.

"Discussion between the conferees continued throughout the day and in consequence thereof certain understandings were reached between the parties, of which the following is a summary:

" 1 . It is the position of the Negotiating Committee of the Cheyenne River Sioux Tribal Council that there are errors in the appraisals prepared by Gerald T. Hart and made under authority of said Public Law 870 , in descriptions, areas of land, quality and quantity of timber extent and value of improvements and in other matters contained in said appraisal.

" 2 . By reason of the objections aforesaid by the said Negotiating Committee of the Cheyenne River Sioux Tribal Council, it is the position of the representatives of the Government that proper steps of inspection and correction of any errors, as alleged, should be taken to effect the pur- pose stated in sub-paragraph (a) of the agreement of January 11, 1952, i.e. ' . . . purpose of resolving factual matters concerning appraisals of land.'

"It was the suggestion which met with the tentative consent of all parties, that a re-examination by a committee should be made of the Hart appraisal and that the committee should consist of two representatives of the Corps of Engineers, two representatives of the Department of Interior and two or more members of the Tribal Council Negotiating Committee. This was stated to be subject to approval of the three principal organizations involved The committee is to be formed as soon as arrangements can be made, and under supervision of their respective departments to report all factual matters concerning appraisal of lands in the Taking Area to their respective superiors.

"It was further agreed that the report of the committee above described should contain the correct description of the land in each tract, the correct acreage thereof, the classsification and grade of the land, the amount and class of standing timber, the description and the estimated value of the improvements within the Taking Area." 


\section{Commission vs. Jury for Condemnation Cases}

\section{Rules of Civil Procedure in Condemnation Cases}

The Constitution of the United States declares that no person may be deprived of his property under the right of eminent domain unless the property is taken for a public use, for just compensation, under due process of law. ${ }^{30}$ The legislative branch of our Government generally decides what is a public use, and the courts usually uphold this decision. The question of what is just compensation is determined by due process of law. When administrative determinations of just compensation are not satisfactory, either party has a right to a court trial. As stated above, the question of what constitutes the best court procedures to ensure "due process of law" needs re-examination periodically because of new situations that arise and changing concepts of public responsibility.

During most of the history of this country, when the Federal Government has exercised the right of eminent domain, the laws of the individual states have been followed. In 1872 Congress enacted the General Conformity Act which provided that the district courts' form, practice, and procedure shall conform as near as may be to that existing in the state courts of each state. Subsequent statutes made this general requirement specifically applicable to condemnations under Federal authority. This was stated in the United States Code in the following manner: ${ }^{31}$

"The practice, pleadings, form and modes of proceedings in causes arising under the provisions of section 257 of this title shall conform, as near as may be, to the practice, pleadings, forms and proceedings existing at the time in like causes in the courts of record of the State within which such district court is held, any rule of the court to the contrary notwithstanding."

Effectiveness of the laws which provided for a uniform system within a state was offset in later years by various legal differences that made exact conformity impossible. In addition to this, over 70 Federal statutes, which sometimes conflicted with one another, governing condemnations for different purposes were enacted. ${ }^{32}$ Any specific Federal enactments on points of procedure also superseded the requirement of conformity.

Agitation for a uniform method of trying civil cases for the whole country resulted in the adoption of the Federal Rules of Civil Procedure in 19.38. But condemnation procedures were not included within the new rules, except as to appellate matters. Hence, much difficulty and confusion were still involved in trying condemnation cases in Federal courts.

${ }^{30}$ U. S. Constitution, 5th and 14 th Amendments

${ }^{31}$ The first Conformity Act was adopted September 24, 1789, 1 Stat. 73, Chapter XX Section 34, p. 92. The second Conformity Act was adopted June 1, 1872, 17 Stat. 196 Chapter CCLV Section 5.

United States Code, Title 40, Section 257. Condemnation of rcalty for sites and other uses; procedure, Section 257 authorizes the Federal Government to acquire real estate for the United States by purchase or condemnation.

${ }^{32}$ H. Doc. 121, 82nd Congress, 1st Session. Many acts merely authorize the exercise of the power without specific declaration as to procedure. Some of these are: 16 U.S.C. 404c-11, 426d, 450aa, 517. Other acts give various government departments power to acquire lands through condemnation proceedings by using laws and procedures of the individual state (33 U.S.C. 591, 24 U.S.C. 78,16 U.S.C. $423 \mathrm{k}$.) 
Under state practices at that time, just compensation was determined by one of three methods: (1) by commissioners; ( 2 ) by commissioners with a right of appeal to and trial cle novo before a jury; and ( 3 ) by a jury, without a commission. A trial before the court, or before the court including a master, who hears the evidence and submits his findings, is another method occasionally used. Approximately five states use only commissioners, 23 states use commissioners and jury trial, and 18 states use only the jury. These methods are stated in approximate terms, as the same state may use diverse methods depending on the circumstances involved. ${ }^{33}$

Procedures used by the courts in handling condemnation cases have been studied by the Supreme Court, the Department of Justice, and other departments and groups, who have been concerned with the question of determining what is "due process of law" and equitable treatment for people whose land is taken for a public purpose. Several years ago, the Supreme Court appointed an Advisory Committee to study this problem and to make recommendations for changes in the procedures used by the courts. The work of this committee resulted in the recommendations of the Supreme Court for amendments to the Rules of Civil Procedure for the United States District Courts. ${ }^{34}$

The most important point under consideration in the report of the Advisory Committee was whether the tribunal that would award the compensation should be a commission or a jury in cases where Con- gress had not made a specific provision on the subject. As mentioned above, there has been some difference of opinion between the Supreme Court and the Department of Justice. The latter department favors the jury system, as expressed in Senate Report 502, 82nd Congress, whereas the Supreme Court favors the commission system. Recently, however, the Department of Justice has handled condemnation cases under the commission system in a few instances. For example, a district court in South Dakota used the commission system to ascertain the value of several tracts condemned by the Army Engineers for Fort Randall Reservoir.

In two instances Congress has specified the kind of tribunal that would fix the compensation to be awarded in condemnation cases. One was in the District of Columbia, where the court is required to order the selection of a "jury" of five from among not less than twenty names drawn from "the special box provided by law." They must have the usual qualifications of jurors and, in addition, must be freeholders of the District and not in the service of the United States or the District. ${ }^{35}$

Use of a commission in condemnation cases was also established for the Tennessee Valley Authority under an Act of Congress. ${ }^{36}$ This Act provides that the United States District Court for the district in which

${ }^{33}$ H. Doc. 121,82 nd Congress, 1st Session, pp. 22-23.

${ }^{34} \mathrm{H}$. Doc. 121, 82nd Congress, 1st Session, Amendments to Rules of Civil Procedure for the United States District Courts.

${ }^{35} \mathrm{H}$. Doc. 121, p. 16 . The provision for the District of Columbia system are found in the United States Code, Title 40 . Sections $361,386$.

${ }^{36}$ United States Code, Title 16, Section $831 x$. 
the land is located shall appoint three commissioners from outside the locality of the land being acquired. The se commissioners must reappraise the property in question and determine the compensation. It is the duty of such commissioners to examine the value of the lands to be condemned, to conduct hearings and receive evidence, and generally to take such appropriate steps as may be proper for the determination of the value of these lands. The commissioners are also required to file a report setting forth their conclusions as to the value of the property. The award of the commission can be appealed before three Federal district judges and the circuit court of appeals by either party in the condemnation suit.

Supreme Court Views. In its study, the Advisory Committee to the Supreme Court made a thorough analysis of the practical operation of the TVA commission system. This committee wrote to every Federal judge who had ever sat in a condemnation case, asking his views as to whether the commission system is satisfactory or whether a jury system is to be preferred. Of 21 responses from the judges, 17 approved the commission and opposed the substitution of a jury system for the TVA. Many of the judges went further and opposed the use of juries in any condemnation case.

Reasons which convinced the Advisory Committee that the commission was preferable in TVA cases were these: ${ }^{37}$

"1. The TVA condemns large areas of land of similar kind, involv- ing many owners. Uniformity in awards is essential. The commission system tends to prevent discrimination and provide for uniformity in compensation. The jury system tends to lack of uniformity. Once a reasonable and uniform standard of values for the area has been settled by a commission, litigation ends and settlement results.

“2. Where large areas are involved many small landowners reside at great distances from the place where a court sits. It is a great hardship on humble... people to have to travel long distances to attend a jury trial. A commission may travel around and receive the evidence of the owner near his home.

" 3 . It is impractical to take juries long distances to view the premises.

" 4 . If the cases are tried by juries, the burden on the time of the courts is excessive."

As a result of this testimony, the Advisory Committee drafted a proposal that the district court shall determine whether the condemnation case will be heard before a commission or jury. This was to be done in all cases where the tribunal is not specified by Congress, as it was in the TVA Act. This provision is as follows:

“( $h$ ) TRIAL. If the action involves the exercise of the power of eminent domain under the law of the United States, any tribunal specially constituted by an Act of Congress governing the case for the trial of the issue of ju st compensation shall be the tribunal for the determination of that issue; but if there is no such specially constituted tribunal any party may have a trial by jury of the issue of just compensation by filing a demand therefor within the time

${ }^{37}$ H. Doc. 121, 82nd Congress, 1st Session, pp. 18-19. 
allowed for answer or within such further time as the court may fix, unless the court in its discretion orders that, because of the character, location, or quantity of the property to be condemned, or for other reasons in the interest of justice, the issue of compensation shall be determined by a commission or three persons appointed by it. If a commission is appointed it shall have the powers of a master provided in subsection (c) of Rule 53 and proceedings before it shall be governed by the provisions of paragraphs (1) and (2) of subdivision (d) of Rule 53. Its action and report shall be determined by a majority and its findings and report shall have the effect, and be dealt with by the court in accordance with the practice, prescribed in paragraph (2) of subdivision (e) of Rule 53. Trial of all issues shall otherwise be by the court." 38

Under the rule mentioned in the above section, the master has power to regulate all proceedings in every hearing, to require the production of evidence, and to put witnesses on oath and examine them. After the hearings are held, the master is to file a report with the clerk of the court along with a transcript of the proceedings, evidence, and exhibits. The court shall accept the master's findings of fact unless clearly erroneous. If either party files objections to the master's report, the court will hold a hearing on this report. After hearing the case, the court may adopt, modify, or reject the report in whole or in part or may receive further evidence or may recommit it with instructions. ${ }^{39}$

The decision whether to use a jury or commission is now left to the district court to decide. In large projects such as those in the Missouri Basin, the courts could use a commission if they cared to do so. The compensation of the commissioners can be fixed or limited by law, as was done in the TVA Act. This would meet the argument that the commission system is more expensive than trial by jury because courts allow commissions too much pay. Even if legislation limiting salaries of commissioners is not passed, the Advisory Committee was still convinced that the commission system was the less expensive of the two. They said, "No figures have been given to the Committee to establish that the cost of the commission system is the greater." 40

Department of Justice Views Expressed in Senate Report 502. In this report, the Department of Justice took the viewpoint that either party should have the right to demand trial by jury, instead of leaving the decision to the court. In approximately 41 states the right to trial by jury exists in condemnation proceedings. Under the conformity system juries were used in trying Federal condemnation cases in these states.

When the Amendments to the Rules of Civil Procedure for the United States District Courts were referred to the Senate Committee on the Judiciary on May 1, 1951, this Committee disagreed with section (h), which was stated above. They said in a report that:

"The committee feels that the basic right to trial by jury is one that should be preserved. The committee feels also that it is preferable to give this right to trial by jury to either party at the outset of the trial so as to avoid the duplication that exists when a jury follows the report of commissioners.

38 United States Code, Title 28, Rules of Civil Procedure, Ru'e 71A, 4h, effective August 1, 1951.

cUnited States Code, Title 28, Rule 53.

40:1. Doc. 121, p. 22. 
"The committee feels, moreover, that it is preferable to have an issue as important as just compensation in condemnation proceedings determined by evidence produced in the presence of a judge. Under a system where the judge is present when the evidence is introduced a proper record is made. If there be errors, appeals may be noted with accuracy so as to provide appellate courts with an adequate record of facts and the legal determinations that have been made." 41

To safeguard the litigants' right to trial by jury, the Senate Judiciary Committee submitted an original joint resolution (S.J. Res. 82) that retained all of the matter contained in the Supreme Court document except that the portion which provides for the use of a commission if the district court so desires was eliminated. ${ }^{42}$ It was also brought out at this time that the proposed Supreme Court action would create the first precedent by which a rule would be promulgated giving a trial court discretion to waive a jury trial. ${ }^{43}$ But Senate Joint Resolution 82 was not passed in time to prevent the $\mathrm{Su}$ preme Court amendments from be- coming effective. ${ }^{44}$ Although the above Committee referred to a "basic right to a trial by jury," it should be pointed out that there is no constitutional right to a trial by jury of the issue of just compensation in eminent domain cases.

\section{Summary of Supreme Court and Justice Department Views}

The Advisory Committee of the Supreme Court favors the commission system for condemnation cases. This position is based on a study of the effectiveness of both methods. Much of its information was obtained from judges who had experience with condemnation cases under both the commission and jury systems.

The Department of Justice has expressed a preference for the jury system. The main reason advanced is "that no man should be denied the right to a trial by jury and particularly in cases as important as the determination of value in condemnation cases."

\section{Comparison of Commission System and Jury Trial}

The following analysis of the merits of the two systems is based on discussions with landowners, lawyers, commissioners, judges, and businessmen who have had experience with either commission or jury.

\section{Commission Makes Actual Appraisal}

A commission award is based on an actual appraisal of the property by the commissioners plus consideration of evidence presented by the Government and the landowner.
The commissioners often view the property before they hold a hearing although this is not required by law. The Commission then holds a hear-

\footnotetext{
${ }^{41}$ Senate Report 502, 82nd Congress, 1st Session, p. 2. ${ }^{42}$ This change in section (h) left out the part in the Supreme Court rules which included, "unless the court in its discretion orders that, ... prescribed in paragraph (2) of subdivision (c) of Rule 53." Otherwise the main portions of the two documents are identical.

${ }^{43}$ Congressional Record, 82 nd Congress, 1st Session, pp. 7863-4.

${ }^{44}$ Under the provisions of Section 2072, Title 28 , United States Code, when the Chief Justice of the Cour reports such rules to Congress not later than the first day of May of the current year, such rules become effective at the expiration of 90 days after they have been reported, unless Congress takes other action before that
} time. 
ing at which both landowner and Government present evidence bearing on value. On the basis of all available information, the commissioners then arrive at a judgment of value.

In contrast, members of a jury are generally not able to view the property and therefore often have no firsthand knowledge of the property involved. The jury must make its decision on the basis of appraisals or testimony presented by the landowner and the Government. An important consideration in the determination of value in a jury trial is the skill of the lawyer in presenting a convincing argument. As the appraisal of land is a matter of judgment about which reasonable men can have wide differences of opinion, it is difficult for 12 people to reach an agreement on one figure. Because of this difficulty the jury award tends to become an averaging of the opinions of the various members of the jury.

A commission award is also an averaging of opinions but there are some fundamental differences.

(1) The commissioners have the distinct advantage of viewing the property and discussing the various elements of value. The collective judgment of these three men is therefore based on a thorough knowledge of what is being valued.

(2) The same commissioners generally hear all the cases in a particular reservoir, and, therefore, become thoroughly familiar with land values in the area.

(3) The U. S. District Judge tries to select men who have had consid- erable experience in appraising land.

(4) The commissioners may also inspect, examine, and consider recent sales of comparable properties in the neighborhood.

For these reasons the commission award is a judgment of value by experienced men who have more complete knowledge of what is being valued than the average member of a jury.

\section{Commission Results in More Uniformity}

It is difficult to get conclusive evidence to show that the commission system results in more uniform and equitable awards than the jury system because no two reservoir areas are exactly alike, nor are there any two farms completely comparable. Consequently, the experience of the commission system in one area and the jury system in another cannot readily be compared. However, evidence obtained in this study indicates that the commission system results in more uniformity of awards than the jury system.

The jury system results in a somewhat erratic determination of value. The following example is a case in point. In an Army Engineers' reservoir on the Cumberland River in Tennessee, one law firm had 40 clients whose land was being condemned. ${ }^{45}$ Twenty-three of the clients agreed to a jury determination of land value in one court case. This was also agreed to by the U. S. District Judge and the attorney representing the Government. It took 21

${ }^{45}$ Limited field work was done in the Cumberland Basin of Tennessee where the Army is building dams. 
days to hear the evidence pertaining to the 23 tracts of land. The jury reached agreement as to value on all except three tracts. The average increase in awards was approximately 10 percent above the appraised value determined by the Army.

Two weeks later another 16 of these 40 clients agreed to have a determination of value in one court case. This time there was a different jury and a different attorney representing the Government, but the same law firm represented the plaintiff. The average increase in awards was more than 100 percent above the Army's appraised value.

The farms in these two groups were all in the same reservoir area. The appraisals were made by the same group of appraisers. It is therefore reasonable to assume the difference in awards was due largely to a difference in the make-up of the jury, or in evidence presented by the Government.

\section{Commission Is Less Time-}

\section{Consuming and More Convenient}

It is more convenient for landowners to appear before a commission than a jury. Most people hesitate to go to court because they have had little experience with lawyers and legal procedures. When they are not accustomed to formal court procedures there is a tendency to feel that they are at a disadvantage. In the verbal contests that arise in formal court hearings, the landowner often feels that the Government has the advantage of more experienced, well-trained lawyers to represent its case.

Landowners who had experience with the commission system say they got a fair hearing. In almost all cases they stated that they preferred a commission hearing to a jury trial.

A lawyer who represented landowners in condemnation cases before both a jury and a commission said that the owners are more satisfied with a commission hearing for the following reasons:

(1) As commission hearings are informal, the landowner feels more at ease when presenting his case.

(2) The commission hearings can be held near the landowner's home. Thus, the problem of attending the hearing and getting competent local witnesses is minimized.

(3) Landowners have confidence in the valuation because the commissioners are able to inspect the property before the hearing.

(4) Commission hearings take less time than jury trials.

\section{Jury Trials Take More Time}

If the cases are tried by juries the burden on the time of the courts is excessive. For example, in some reservoir areas along the Cumberland River, Tennessee, there is an 8- or 9 -year delay in hearing condemnation cases. This delay can be attributed to several causes:

(1) About 25 to 30 percent of the owners refused the price offered by the Army Engineers, and condemnation followed, thereby increasing the work load of the courts.

(2) The district judge has a large area to cover and is therefore able to spend only a limited amount of time each year hearing condemnation cases. 
Table 1. TVA Condemnation Cases up to June 30, 1950

\begin{tabular}{|c|c|c|}
\hline I:em & $\begin{array}{c}\text { Heard by } \\
\text { Commission }\end{array}$ & $\begin{array}{l}\text { Compromised without } \\
\text { Commission Hearing }\end{array}$ \\
\hline Number of cases & 492 & 470 \\
\hline Offers & $\$ 2,911,426$ & $\$ 489,7.32$ \\
\hline Awards .. & $\$ 3,524,588$ & $\$ 517,268$ \\
\hline 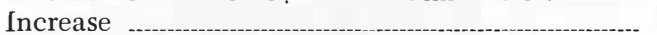 & $\$ 613,162$ & $\$ 27,536$ \\
\hline Percentage increase over TVA appraised value & 21 & 5.6 \\
\hline
\end{tabular}

*Compromise settlements are sometimes made after condemnation proceedings are started but before the actual date of the commission hearing.

Source: Data obtained from TVA records.

(3) Sometimes a jury trial will take several days, whereas a commission hearing seldom takes more than two days.

These delays are costly to the public as well as the landowner. The courts cannot expedite other business as effectively when they are over - burdened with problems which could be handled by the administrative agency.

These delays are burdensome to the landowner in several ways. First, a pending court trial is a worry to most people. Second, when there are delays of many years, it is more difficult to present complete testimony.

\section{Summary of Commission Experience by TVA}

A total of 492 TVA condemnation cases involving reservoir lands was heard by a commission to determine just compensation. The average increase in the award by the commission over the original offer by TVA was 21 percent. In addition to these cases, there were 470 cases in which an owner had refused to sell, but a compromise settlement was arrived at prior to the hearing. The average increase in prices paid for these cases was 5.6 percent above the orig- inal offer (Table 1). The commission also heard 509 cases in which the only issue was clarification of title.

The TVA Act provides that either party in a condemnation case may appeal the ruling of the commission to the district judge who, in turn, names two other judges, and the three hear the case. By June 30, 1950, 259 cases were appealed to the three-judge court. (Table 2). Of these, 136 were withdrawn by either TVA or the owner. Out of the remaining 123 cases, 69 were affirmed. In 25 cases, the judges increased the award. The total increase for these 25 tracts was $\$ 30,936$. In 29 cases, the awards were reduced below the awards of the commission. In these cases there was often a substantial reduction. The total reduction for the 29 cases was $\$ 162,707$, or an average reduction of $\$ 5,589$ per tract.

Table 2. TVA Condemnation Cases Appealed to 3-Judge Court

\begin{tabular}{lc}
\hline \hline item & Number \\
\hline Cases appealed & 259 \\
Cases withdrawn & 136 \\
Cases heard & 123 \\
Commission awards affirmed & 69 \\
Commission awards raised & 25 \\
Commission awards reduced & 29 \\
\hline
\end{tabular}


In over half the cases heard by the three judges, the commission awards were confirmed. The rest were about equally divided between those increased and those decreased.

\section{Comparison of Land Acquisition Experience in Army Engineer and TVA Reservoirs}

Interpretation of just compensation by legal and administrative agencies has been discussed. Procedures used by the courts and different administrative agencies have also been analyzed. The combined effect of these differences becomes apparent in a comparison of two reservoirs, the one developed by the TVA and the other by the Army.

Wappapello Reservoir in Missouri and Kentucky Reservoir in the Tennessee Valley provide a good basis for comparison. The land for the former was acquired by the Army Engineers, and for the latter by TVA. The acquisition took place during the same period in both cases. The type of farming and cultural pattern had much in common.

The essential differences in procedures were:

(1) The two agencies used different interpretations of the fair market value concept.

(2) The appraisal procedures, such as mapping, background stud.ies, and inspection of property, used by the TVA were more thorough than those of the Army.

(3) TVA allowed landowners the use of the farm without rent for two or three years after they had received payment. In some cases the Army Engineers acquired a large portion of the land just before the closing of the dam. When it was acquired in advance, the land was leased to the former owner until it was needed for flood storage purposes.

(4) TVA carried on a relocation program in cooperation with the Extension Service.

(5) When the land was acquired through condemnation, the TVA cases were heard by a three-man commission and the Army Engineers' cases were heard by a jury.

(6) TVA paid the owners sooner than the Army did.

It is difficult to isolate the effects of each of these differences. However, a comparison of the prices paid with the appraised market value and the general satisfaction of the people in the two reservoirs shows some of the combined effect of these differences.

In the Army Engineers' reservoir, 25 percent of the tracts were acquired through condemnation; whereas in the TVA reservoir only 3 percent of the tracts were thus acquired (Table 3 ). A low rate of condemnation is not always a meaningful measure of the success of a land acquisition program. It is reported that in some TVA reservoir areas, people were discouraged from taking court action by being told they could not win against the Government. A similar type of situation was reported in the Wappapello 
Table 3. Comparison of the Price Paid with Appraised Market Value in Army Engineers' and TVA Reservoirs

\begin{tabular}{|c|c|c|c|c|c|}
\hline \multirow[b]{3}{*}{ Acquisition } & \multicolumn{5}{|c|}{ WAPPAPELLO RESERVOIR (Army Engineers)*† } \\
\hline & Tracts & $\begin{array}{l}\text { Percent } \\
\text { of Total }\end{array}$ & $\begin{array}{l}\text { Appraised } \\
\text { Market Value }\end{array}$ & Price Paid & $\begin{array}{l}\text { Price Paid } \\
\text { as Percent } \\
\text { of Appraised } \\
\text { Value }\end{array}$ \\
\hline & Number & Percent & Dollars & Dollars & Percent \\
\hline Optioned below appraised value .-...... & 79 & 12 & 160,627 & 149,540 & 93.1 \\
\hline Optioned at or above appraised value & 419 & 63 & 930,892 & 979,225 & 105.2 \\
\hline $\begin{array}{l}\text { Condemned but settled by agreement } \\
\text { without trial or commission hearing }\end{array}$ & 117 & 18 & 358,522 & 416,229 & 116.1 \\
\hline $\begin{array}{l}\text { Condemned and settled by trial } \\
\text { or agreement after trial }\end{array}$ & 45 & 7 & 207,357 & 299,192 & 144.3 \\
\hline \multirow[t]{3}{*}{ Totals } & 660 & 100 & $1,657,398$ & $1,844,186$ & \\
\hline & \multicolumn{5}{|c|}{ KENTUCKY RESERVOIR (TVA) +} \\
\hline & Tracts & $\begin{array}{l}\text { Percent } \\
\text { of Total }\end{array}$ & $\begin{array}{l}\text { Appraised } \\
\text { Market Value }\end{array}$ & Price Paid & $\begin{array}{l}\text { Price Paid } \\
\text { as Percent } \\
\text { of Appraised } \\
\text { Value }\end{array}$ \\
\hline Acquisition & Number & Percent & Dollars & Dollars & Percent \\
\hline $\begin{array}{l}\text { Optioned below appraised value } \\
\text { Optioned at or above appraised value }\end{array}$ & $\begin{array}{l}\text { none } \\
6,837\end{array}$ & 97 & $12,888,799$ & $12,888,799$ & 100 \\
\hline $\begin{array}{l}\text { Condemned but settled by agreement } \\
\text { without trial or commission hearing } \\
\text { Condemned and settled by trial }\end{array}$ & 130 & 2 & 221,873 & 221,873 & 100 \\
\hline or agreement after trial & 80 & 1 & 260,903 & 308,571 & 118.3 \\
\hline Totals & 7,047 & 100 & $13,371,575$ & $13,419,243$ & \\
\hline
\end{tabular}

*Experience in more recent Army Engineers' projects in the Cumberland shows similar results.

+"Local Effects of the Wappapello Reservoir, Wayne County, Missouri, with Suggestions for Lessening Undesirable Effects of Reservoirs," Missouri Division of Resources and Development, Jefferson City, Mo., February 1950.

¥Data for Kentucky Reservoir obtained from TVA.

area. ${ }^{46}$ When people believed this and later learned that the court awards were often higher than the appraised value, they were resentful. It would be better to have a few more court cases than resentment on the part of the public. In both the Army and TVA reservoirs, some condemnation cases were settled prior to a court hearing. In the Wappapello Reservoir, 18 percent of the total number of tracts were settled by agreement without trial. The average prices paid were 16 percent above the appraised value. In the Kentucky Reservoir, 2 percent of the total number of tracts were acquired by settlement prior to a commission hearing. In total, there was no increase in prices paid above the appraised price.

In the Army Engineers' reservoir, the settlements by trial or agreement after trial were 44 percent above the appraised value; whereas in the TVA cases the court awards were approximately 18 percent above the initial TVA offer.

\footnotetext{
46"Local Effects of the Wappapello Reservoir, Wayne County, Missouri, With Suggestions for Lessening Undesirable Effects of Reservoirs," Missouri Division of Resources and Development, Jefferson City, Missouri, February 1950.
} 


\section{Summary and Conclusions}

People need assurance that they will get just compensation when their property is taken for a public purpose under the right of eminent domain. Procedures used by the Government for land acquisition need to be fair and reasonable to the people involved. This study has been concerned with the following:

(1) The interpretation of the concept of just compensation.

(2) Analysis of the legal and administrative procedures used in the determination of just compensation.

(3) Methods used in making adjustments with local units of government.

(4) Procedures used in land management.

(5) Application of TVA experience to problems in the Missouri Basin.

The courts have held that "just compensation" shall be construed to mean "fair market value." This fair market value the courts have further defined as that price which a willing buyer would pay a willing seller when neither party is compelled to buy or sell. The courts have also held that the landowner should be in the same pecuniary position before and after the taking. They have declared an owner should be made "whole." However, the courts and legal profession have placed the emphasis on the "willing buyer-willing seller" idea in the determination of just compensation.

TVA, in contrast to other Federal agencies, has not considered itself bound by this restricted concept of just compensation when buying land. Furthermore, it considers itself instructed by the wording of the TVA Act to give full consideration to the interests of the people of the Basin. Hence, it has adopted appraisal procedures, and other measures, which take into consideration the many costs that fall upon the displaced. This concept results in a different price policy, and in the main the people are satisfied with the way they have been treated. Relatively few are dissatisfied.

When owners refused what TVA considered a liberal offer and the land was condemned, TVA followed the restricted concept of willing buyer-willing seller. This is the same concept as other Federal agencies use, not only in condemnation, but also when appraising for purchase before condemnation becomes necessary.

Legal procedures used also affect the determination of just compensation. Opinions differ as to whether condemnation cases should be heard by a commission or a jury. The TVA Act provided for a commission system for hearing condemnation cases. It is the conclusion of this study that if reasonably competent commissioners are selected the commission system has the following advantages:

(1) The commission award is an actual appraisal. Commissioners are able to view the property and arrive at an independent appraisal prior to the hearing.

(2) Awards are more consistent. Commissioners become experienced at judging land values in a given res- 
ervoir area and are therefore able to grant more uniform awards than juries selected for each case.

(3) A commission hearing is more convenient for the landowner, and he feels more at ease in presenting his case.

(4) When the jury system is used, the burden on the time of the courts is excessive. Commission hearings take less time.

Whether a commission system or a jury system is used, the right to a court trial is provided as a last resort when voluntary agreement is not possible. It was not the intent of the constitutional provisions that the courts should assume the responsibility of making appraisals of all property acquired for a public use. Court action was to be used only when the administrative agency was unable to reach agreement with the landowner and the land could not be purchased voluntarily. ${ }^{47}$

Court decisions generally prescribe the broad limits within which the administrative agencies make their determination of value. The administrator and landowners are always guided by their anticipation of what the courts will do. Actual determination of just compensation is made by the administrative agencies in the majority of cases. The TVA, for example, reported that it acquired 97 percent of the tracts ( or 94 percent of the acreage) without resorting to court action. Administrative procedures used are therefore probably more important to the people involved than the court procedures. Consequently, it is important to try to benefit from the experience of agencies that have been suc- cessful in their land acquisition program.

People displaced by TVA reservoirs are generally well satisfied with the procedures used in the determination of just compensation. Approximately 20,000 farms were bought. As noted above, only a small percentage were acquired by condemnation. The average increase in awards granted by the commission was 21 percent above the appraised price. The main reasons for the comparative success of the TVA land acquisition program are:

(1) "Fair market value" was interpreted to mean the price required to leave the landowner in the same financial position after the taking as he was before.

(2) A detailed mapping system made possible a more accurate appraisal.

(3) A background study of the reservoir area provided a firm base for judging land values. The study was designed to assemble all information having a bearing on land values. This work was done by members of the appraisal staff to give them an opportunity to become thoroughly familiar with the area to be appraised.

(4) Appraisers were required to invite the landowner to accompany them when the first appraisal was made. Appraisers were also instructed to treat the landowner with respect at all times.

(5) The landowner received payment for his farm promptly and us-

\footnotetext{
${ }^{47}$ When the land must be acquired quickly, the Justice Department can institute condemnation proceedings for an entire area. However, in cases of this kind the administrative agency is usually instructed to acquire as much land as possible on a voluntary basis.
} 
ually from two to three years before the land was needed for the reservoir. This gave him an opportunity to look for another farm and to make a gradual transition. When the owner has time to plan the change, the loss of income resulting from the disruption of a going concern is minimized.

(6) The relocation program carried on by the Extension Service in cooperation with the TVA helped people get re-established in their new localities. This program also helped check increases in land values resulting from the land acquisition program.

A few people are critical of some TVA land buyers who either told landowners that they could not be successful in a court case with the Government, or implied it.

A few people in each reservoir area also are antagonistic toward the TVA. A part of the explanation for this is that TVA personnel in some cases postponed appraisal and purchase of land where they thought dealing with the owner would be difficult. These people had less time between date of payment and time they had to move.

In addition to the problems of land acquisition, there are related problems of reservoir management. These problems include land management, leasing recreational areas, selling of excess land, adjustments with local units of government for loss of tax revenues, and other problems. In dealing with these problems the TVA has introduced some new ideas that have proved effective. TVA endeavored to put to use for agricultural, recreational, com- mercial, industrial, and other uses lands in its custody that had been acquired for reservoir purposes.

Renting of shore lands available for agricultural use was handled by TVA with the help of an advisory association of farmers until about 1950, when the volume of such lands had shrunk through sale and through transfer to other public agencies. In almost all instances, TVA acted on the recommendation of these local associations. The associations recognized the need for stability of tenure and a sound land use plan. These considerations were thought to be very important in determining who should use the land.

Until recently, recreational areas were usually rented with 19-year leases. Rates on the larger boat docks and other recreational areas are based on a certain percentage of gross income. The present rate, applicable to unimproved sites, is 3 percent of the first $\$ 20,000,2$ percent of the next $\$ 10,000$, and 1 percent of anything above $\$ 30,000$. This system has proved effective in encouraging the lessee to expand operations and thus provide better services to the public.

For small recreational operations a license is granted at a flat fee to facilitate negotiations with those who are not prepared to keep detailed records.

Surplus lands are sold for the highest and best use as ascertained by TVA staff and state and local public agency review. No provision has been made for enforcement of a particular use except for lands sold for recreational purposes. TVA sells land for recreational use subject to 
restrictions enforceable either (a) among several purchasers, as in a subdivision, or (b) under a reversionary clause for lands sold under Section 4KA of the TVA Act.

When land along the lakes is sold for agricultural or forestry purposes, TVA retains for the public the right of access to 250 feet from the waterline for landing, picnicking, hunting, and fishing. This provision will benefit the public greatly in the future as demands on limited recreational areas expand.

When making payments to local units of government for loss of tax revenue, TVA tried to make reasonable adjustments so communities would be in as good a position as possible after the program was carried out. Payments to counties in lieu of taxes represent replacement of former ad valorem taxes on electric utility properties purchased by TVA and the portion of reservoir lands allocated to power (now 41\%2 percent in the case of multipurpose dam projects).

When roads or schools are disrupted by the program, TVA offers to replace the roads or make cash settlement. Usually the local units of government chose to have the TVA replace the roads. Cash settlements were made for schools.

\section{Applications to Missouri Basin}

Several of the ideas and procedures used by the TVA in its land acquisition and management experience are applicable to the Missouri Basin and other areas. The interpretation of the concept of fair market value to mean "the price required to place the owner in the same financial position before and after taking" can be generally applied to the acquisition of private land under the right of eminent domain. This is more equitable than the use of the customary court interpretation of what a "willing buyer would pay a willing seller." Because of differences of opinion as to what an administrative agency can do under existing rules, it is desirable for administrative agencies who operate under the "willing buyer-willing seller" interpretation to explore the possibility of using the interpretation used by TVA. If this cannot be done under existing law, the possibility of legislation to establish this interpretation should be explored.

The commission system for hearing condemnation cases works well in the Tennessee Basin. It showed sufficient merit that its use should be given consideration in the Missouri Basin. As long as competent commissioners are appointed, it offers a way of avoiding some of the problems reported in connection with the usual court trials.

Procedures used by TVA for land acquisition can help reduce some of the existing dissatisfaction with present procedures in the Missouri Basin.

TVA provides for a training program for its appraisal staff. These men are given instruction in appraisal procedures and in methods of dealing with the people. Most people displaced by TVA reservoirs say that TVA personnel try to be fair and courteous. This reaction is due to a wise selection of personnel as well as a sound training program.

The background study made by 
TVA before appraisals began, the procedure used to insure that landowners are contacted before appraisals are made, and the prompt payment (usually within 30 days) can be adopted by other agencies. Through adequate planning, TVA was able to allow farmers two to three years to plan their move from one farm to the other. Landowners received payment for their farms and were allowed to continue to farm without rent until TVA needed the land. This idea is applicable in other areas except that the time allowed should vary depending on the type of agriculture in a given area. It is desirable for administrators to allot sufficient money for land acquisition so those in charge of land purchase can plan ahead and thereby avoid the rush to buy the remaining land just before closing the dam.

The family relocation program carried on by the Extension Service in cooperation with TVA has been helpful to many people. However, an equally extensive program is not necessary in areas such as the upper part of the Missouri Basin. Because the area is sparsely settled and people often move long distances to relocate, it is impractical to try to show landowners property that is for sale. It would, however, be helpful to keep a listing of farms and ranches for sale in several counties surrounding the reservoir. This can be done by the Extension Service.

The TVA method of making adjustments with local units of government has proved more satisfactory than methods used in the Missouri Basin.

Adjustments made by TVA in payments to counties for loss of tax revenues are based on replacement of former taxes on purchased properties. Payments to state governments for loss of tax revenues are based upon a percentage of power revenues apportioned by states on the basis of location of TVA power property and power sales. TVA does not make payments in lieu of taxes directly to municipalities. The state and local units of government are allowed to use the money as they see fit without any restrictions by TVA.

The method used by TVA for making payments in lieu of taxes was effective in meeting the needs of that particular area. This procedure, however, would not necessarily be applicable in other areas. The important point is that a method of payment was developed that was satisfactory to all concerned. Satisfactory methods of payment need to be developed in other areas.

The Army pays 75 percent of its rental returns to the county for loss of tax revenue. This fixed payment does not always provide a payment in relation to need. The Bureau of Reclamation has no authority to make payments for loss of tax revenues. One explanation is that such payments are not necessary because local communities benefit from irrig a t i o n developments. Although there are benefits from irrigation development, the communities that benefit are usually not the ones that are adversely affected by loss of tax revenue from lands acquired. Procedures used by different Federal agencies are not uniform. Methods used by TVA have proved satisfac- 
tory to the people in the Tennessee Valley. A more thorough analysis of procedures used by the Federal Government in making payments in place of taxes for property acquired is needed.

The land management program of TVA has been guided by three basic ideas which are applicable in the Missouri Basin:

(1) Reliance on the advice and consultation of responsible local agencies and organizations. This was accomplished through land use associations, planning boards, and similar groups.

(2) The need for maximum stability and tenure consistent with TVA's primary program purposes. TVA has encouraged sound land use practices, and has also introduced flexible rental rates for agricultural lands.

(3) TVA attempts to transfer as many functions as possible to private owners or local units of government. Lands suitable for recreational development are sold to private concerns or transferred to county or state governments.

\section{Appendix}

\section{Reservoir Studies}

A number of studies have been made of the local problems that arise in connection with the construction of reservoirs. As this report draws upon those studies, a brief description is included.

"In 1940, the University of Missouri undertook a study of the social and economic effects of constructing the Wappapello Flood Control reservoir located in southeastern Missouri." 48 "This was about two years after construction had been started on the dam. Of the 304 farm families in the reservoir site, 244 were interviewed to learn about their problems of relocation and readjustment. A report on this study was published by the University in 1941 .

"In 1949, a number of agencies of the State of Missouri and the federal government undertook another study of the local effects of Wappapello reservoir. By this time, the res- ervoir had been in operation about eight years and the displaced families had relocated elsewhere. In this study, a total of 80 farm families and 30 city families were interviewed, the latter from the City of Greenville which had moved out of the reservoir site. Of the 80 farm families interviewed, 20 had operated reservoir land in 1948 under lease from the government; 32 had lived in the reservoir site in 1940 but in 1948 were farming elsewhere; 28 had lived in the reservoir site in 1940 but by 1948 had retired or were no longer farming. Probably about onefourth of the farm families directly affected by the construction of the reservoir were interviewed. The 30 city families interviewed constituted about one-third of the population of Greenville at the new location.

\footnotetext{
48" "Reducing Adverse Effects of Reservoirs," Great Plains Council Pub. No. 6, Agricultural Experiment Station, Kansas State College, Manhattan, Kansas, Cir. 293,
} October 1952, pp. 28-29. 
This study was made to learn more about the problems that arise in connection with land acquisition and management, effects on local governments, and problems of moving a town, and also to learn how satisfactory the displaced families found their new farms or new communities. A report on this study was published in 1950 by the Missouri Division of Resources and Development.

"In 1947, a number of agencies of the State of Missouri and the federal government started a study on the probable effects of the proposed South Grand and Stockton Flood Control reservoirs. Field surveys were made of the resources in the area and of the possible effects of operation of the reservoir on the agricultural, mineral, and timber resources; effects on recreational developments, trade territories, and on local governments. This report was published in 1948 by the Missouri Division of Resources and Development.

"In 1950, the Nebraska Co-ordinating Committee for Missouri Basin Resource De ve lop m e n t named a subcommittee to make an exploratory survey of local problems in connection with Nebraska reservoirs. From 35 to 40 farmers, town residents, local officials, and businessmen were interviewed to learn what problems had come up in connection with the construction of the Harlan County reservoir. Construction of this reservoir had been start- ed in 1946 and was practically completed in 1951. It was built primarily for flood control but it will also provide storage for irrigation. Similarly, study was made of the local problems that came up in connection with Trenton, Enders and Medicine Creek reservoirs. The latter two reservoirs were completed in 1949-50 and Trenton reservoir will be completed by 1953 . These three reservoirs were built primarily for irrigation purposes but they also have storage for flood control. Reports were prepared on problems found in connection with these four Nebraska reservoirs and presented to the co-ordinating committee along with a report on research needed.

"In 1951, the South Dakota Coordinating Committee for Missouri Basin Development named a subcommittee to study local impacts of inundation of land in reservoir areas. A total of 57 people were interviewed at the Fort Randall site, a reservoir built primarily for flood control but which will also provide power. Construction of the dam was about half complete at the time of the survey. Study also was made of problems at Shadehill reservoir, built primarily for irrigation and completed in 1951. A report was presented to the co-ordinating committee on problems found at these two reservoirs."

All of these reports contain many suggestions for lessening the undesirable effects of reservoirs. 